\title{
Seasonal and scale-dependent variability in nutrient- and allelopathy-mediated macrophyte-phytoplankton interactions
}

\author{
P. Lombardo(1),(2),(3),, M. Mjelde ${ }^{(1)}$, T. Källqvist ${ }^{(1)}$, P. Brettum(1)
}

Received November 13, 2012

Revised April 7, 2013

Accepted May 15, 2013

Key-words: Ceratophyllum demersum, Elodea canadensis, nutrients, allelopathy, alternate stable states in shallow lakes

\section{ABSTRACT}

macrophyte-phytoplankton interactions were investigated using a dual laboratory and field approach during a growing season, with responses quantified as changes in biomass. Short-term, close-range interactions in laboratory microcosms always led to mutual exclusion of macrophytes (Elodea canadensis or Ceratophyllum demersum) and algae (Raphidocelis subcapitata, Fistulifera pelliculosa) or cyanobacteria (Synechococcus leopoliensis), suggesting regulation by positive feedback mechanisms, progressively establishing and reinforcing a "stable state". Laboratory results suggest that close-range regulation of $R$. subcapitata and F. pelliculosa by macrophytes was primarily via nutrient $(N, P)$ mediation. Sprig-produced allelochemicals may have contributed to inhibition of $S$. leopoliensis in C. demersum presence, while $S$. leopoliensis was apparently enhanced by nutrients leaked by subhealthy (discolored leaves; biomass loss) E. canadensis. Seasonal changes in algal growth suppression were correlated with sprig growth. Marginal differences in in situ phytoplankton patterns inside and outside monospecific macrophyte stands suggest that the nutrient- and/or allelopathy-mediated closerange mechanisms observed in the laboratory did not propagate at the macrophyte-stand scale. Factors operating at a larger scale (e.g., lake trophic state, extent of submerged vegetation coverage) appear to override in situ macrophyte-phytoplankton close-range interactions.

\section{RÉSUMÉ}

Variabilité saisonnière et dépendante de l'échelle dans les interactions macrophytephytoplancton liées aux nutriments et à des relations d'allélopathie

\begin{abstract}
Mots-clés : Ceratophyllum demersum, Elodea canadensis,

Les interactions macrophytes-phytoplancton ont été étudiées à l'aide d'une approche double de laboratoire et de terrain au cours d'une saison de croissance, avec des réponses quantifiées comme les changements dans la biomasse. Les interactions à court terme et à courte portée dans des microcosmes de laboratoire ont toujours conduit à l'exclusion mutuelle entre des macrophytes (Elodea canadensis ou Ceratophyllum demersum) et des algues (Raphidocelis subcapitata,
\end{abstract}

(1) Norwegian Institute for Water Research (NIVA), Freshwater Department, Gaustadalléen 21, 0349 Oslo, Norway

(2) Limno Consulting, via Bedollo 303, 00124 Rome, Italy

(3) Department of Civil, Architectural and Environmental Engineering (DICEAA) - M. Giustini Ecology Lab, Coppito Science Center - University of L'Aquila, 67100 L'Aquila, Italy

* Corresponding author: p.lombardo@limnoconsulting.com, physa@tiscali.it 
nutriments, allélopathie, états stables alternatifs en lacs peu profonds
Fistulifera pelliculosa) ou cyanobactéries (Synechococcus leopoliensis), suggérant une régulation par des mécanismes de rétroaction positive, s'établissant progressivement et renforçant un «état stable ». Les résultats de laboratoire suggèrent que la régulation à courte portée de $R$. subcapitata et $F$. pelliculosa par les macrophytes était principalement due aux éléments nutritifs $(N, P)$. Les composés allélochimiques produits par les brins de macrophyte peuvent avoir contribué à l'inhibition de S. leopoliensis en présence de C. demersum, tandis que S. leopoliensis a apparemment été renforcée par les éléments nutritifs produits par $E$. canadensis en mauvais état (feuilles décolorées, perte de la biomasse). Les changements saisonniers comme la suppression de la croissance des algues ont été corrélés avec la croissance du brin. Des différences marginales in situ dans les dynamiques du phytoplancton à l'intérieur et à l'extérieur des peuplements monospécifiques de macrophytes suggèrent que les mécanismes rapprochés liés aux nutriments et/ou à l'allélopathie observés en laboratoire ne se développent pas à l'échelle des formations de macrophytes. Les facteurs intervenant à plus grande échelle (par exemple, l'état trophique du lac, l'étendue de la couverture de végétation submergée) semblent l'emporter sur les interactions à courte portée macrophytes- phytoplancton in situ.

\section{INTRODUCTION}

Mutual exclusion between submerged macrophytes and phytoplankton is at the core of the "alternate stable states" theory for shallow lakes, according to which such lakes exist in one of two states: either clear-water and macrophyte-dominated, or turbid and phytoplanktondominated, over a wide range of nutrient concentrations (Scheffer, 1998). Though several mechanisms have been proposed and successfully tested in controlled experiments to explain mutual exclusion of macrophytes and phytoplankton, their relative importance and true in situ effectiveness remain open to debate. For example, macrophytes may not be as effective in absorbing water-column nutrients in the field as they are in typical short-term laboratory experiments (Lombardo and Cooke, 2003), and direct competition for water-column nutrients between well-established (i.e., midsummer) in situ macrophytes and phytoplankton is unlikely (Lehmann et al., 1994; Schulz et al., 2003). Also, though proven in the laboratory (e.g., Körner and Nicklisch, 2002; Gross et al., 2003) or in controlled field experiments (Jasser, 1995; Hilt et al., 2006), and suspected as a cofactor in maintaining high water transparency in richly vegetated lakes (Blindow et al., 2002; Hilt and Gross, 2008), in situ macrophyte allelopathy against phytoplankton is particularly difficult to prove (Gross et al., 2007).

Further complications arise from potential interactions among such mechanisms and between such mechanisms and environmental conditions, such as light availability, lake area, or trophic state (Gross, 2003; van Geest et al., 2003). The extent of sediment coverage by submerged vegetation for the macrophyte-dominated, clear-water state to become stable also is topic of discussion (Jeppesen et al., 1990; Mjelde and Faafeng, 1997; Blindow et al., 2002), and even less is known about how much macrophyte coverage may influence the in situ effectiveness of the mechanisms regulating macrophyte-phytoplankton interactions.

As both macrophytes and phytoplankton follow seasonal growth and metabolic cycles (e.g., Pip and Philipp, 1990), plant-algae interactions may change during the course of a growing season. Possible seasonal changes in close-range macrophyte-algae interactions may have implications at the ecosystem scale. For example, if phytoplankton inhibition by macrophytes is stronger at the beginning of the growing season, year-long lake state (clear-water or turbid) may depend on spring conditions. Knowledge about seasonal cycles in plantalgae/cyanobacteria ecology may prove useful in management decisions, assisting lake managers in choosing not only what techniques to use for the problem at hand, but also when to apply such techniques most effectively. Yet, studies addressing seasonal aspects have started to appear only recently in the literature (e.g., Blindow et al., 2002; Hilt et al., 2006). 
We have studied macrophyte-phytoplankton interactions during a growing season (June-September) using a dual laboratory and field approach. Our intent was to shed some light on 1. as yet incompletely understood (e.g., Gross et al., 2007; Hilt and Lombardo, 2010) close-range, allelochemical- and nutrient-mediated macrophyte-phytoplankton interactions; 2. how such mechanisms may propagate at the scale of in situ macrophyte stands; and 3. temporal changes in such interactions along a growing season, also little understood as of yet. Laboratory experiments using freshly field-collected macrophytes focused on the potential roles of allelopathy and nutrient $(N, P)$ dynamics in shaping close-range, speciesspecific macrophyte-cyanobacteria/algae interactions. Field data from inside and just outside monospecific macrophyte stands were discussed comprehensively with the laboratory results and with lake ecosystem characteristics to assess the relative importance of the most plausible mechanisms in shaping macrophyte-phytoplankton interactions at three different spatial scales: microhabitat (close-range), macrophyte stand (medium-range), and whole lake (large-scale).

\section{METHODS}

\section{> DESCRIIPTION OF FIELD SITES}

Ceratophyllum demersum L. was collected in Spiradammen ("Pond Spira"), a small $(A=$ $0.3 \mathrm{ha})$ and shallow $\left(\bar{z}=1.3 \mathrm{~m} ; z_{\max } \sim 2.5 \mathrm{~m}\right)$, mesotrophic and richly vegetated clearwater lake (Secchi depth to bottom). Elodea canadensis Michx. originated from the outlet area of Østensjøvatn ("Lake Østen"), an equally shallow but larger ( $A=3.1$ ha; $\bar{z}=1.9 \mathrm{~m}$; $z_{\max }=3.2 \mathrm{~m}$ ), nutrient-rich and turbid lake. Both lakes are located in southeastern Norway close to the Oslofjord coastline (Figure A-1); Spiradammen $\left(59^{\circ} 50^{\prime} 9^{\prime \prime} \mathrm{N}, 10^{\circ} 29^{\prime} 52^{\prime \prime} \mathrm{E}\right)$ is located near the city of Asker, while Østensjøvatn (59 $\left.53^{\prime} 40^{\prime \prime} \mathrm{N}, 10^{\circ} 49^{\prime} 49^{\prime \prime} \mathrm{E}\right)$ is located in the SE suburbs of Oslo. Østensjøvatn is periodically flushed with nutrient-poor water as part of management efforts aimed at curbing eutrophication effects (Gabestad, 2001). Each plant species dominated in its origin lake, though the abundance of $E$. canadensis in Østensjøvatn is variable, and was particularly low during the sampling year (2003), with no stands reaching the surface. Plant stands were not sufficiently large for a meaningful analysis in mid May, but they had reached a sufficient size by mid June. The submerged vegetation covered $\sim 15-20 \%$ of the sediment area of Østensjøvatn and virtually all Spiradammen surface area during peak biomass (July-August).

\section{> LABORATORY EXPERIMENTS}

Four identical laboratory experiments were run at 4-5-week intervals, spanning a growing season. Initial trial dates were 11 June, 14 July, 24 August, and 29 September 2003; each trial lasted $4 \mathrm{~d}$. Growth of test organisms (unicellular algae and cyanobacteria) was monitored daily in the presence or absence of macrophyte sprigs. Each trial used freshly field-collected macrophytes and inocula from long-term algal/cyanobacterial cultures under controlled, identical laboratory conditions, so that between-trial differences (if any) could be ascribed to differences in macrophyte condition.

Laboratory experiments adapted standard methods for growth inhibition bioassays using unicellular autotrophic test organisms (OECD, 2011). Test organisms were chosen among those listed in OECD (2011) to represent "typical" chlorophytes [Raphidocelis (=Pseudokirchneriella) subcapitata (Korshikov) G. Nygaard, J. Komárek, J. Kristiansen \& O.M. Skulberg (=Selenastrum capricornutum Printz)], diatoms [Fistulifera pelliculosa (Brébisson) Lange-Bertalot (=Navicula pelliculosa (Brébisson ex Kützing) Hilse)], and cyanobacteria [Synechococcus leopoliensis (Raciborski) Komrek]. Inocula were taken from preexisting long-term monospecific, nonaxenic, clone laboratory cultures at NIVA's Algal Laboratory. Such cultures were originally isolated from natural populations, and are periodically reseeded to avoid 
cellular overgrowth and medium exhaustion. Natural populations of $R$. subcapitata and $S$. leopoliensis are typically planktonic, while F. pelliculosa may be found also as a benthic form. Laboratory experiments used $300 \mathrm{~mL}$ of OECD TG 201 (=ISO 8692) liquid algal growth medium (ISO, 2004; OECD, 2011) in clear-glass 1-L Erlenmeyer flasks. The OECD TG 201 growth medium has a $\mathrm{pH}$ of 8.1 , is rich in $\mathrm{HCO}_{3}^{-}$to buffer possible photosynthesis-driven changes in $\mathrm{pH}$, and provides high quantities of nutrients in readily available form for both algae and plants (364 $\mu \mathrm{g} \cdot \mathrm{L}^{-1}$ of $\mathrm{P}$, supplied as $\mathrm{PO}_{4}$, and $3928 \mu \mathrm{g} \cdot \mathrm{L}^{-1}$ of $\mathrm{N}$, supplied as $\left.\mathrm{NH}_{4}^{+}\right)$. The medium was supplemented with $\mathrm{Na}_{2} \mathrm{SiO}_{3} \cdot 9 \mathrm{H}_{2} \mathrm{O}$ for tests with $\mathrm{F}$. pelliculosa to obtain a Si concentration of $1400 \mu \mathrm{g} \cdot \mathrm{L}^{-1}$. Such nutrient concentrations are designed to allow unrestricted exponential growth within the standard 3-day test duration (OECD, 2011). The complete recipe for the OECD TG 201 growth medium is in OECD (2011). Flasks were acid-washed before use.

Growth of $R$. subcapitata, F. pelliculosa, and S. leopoliensis was monitored in separate flasks in the presence or absence of $C$. demersum or E. canadensis (Figure A-2). Each experimental condition was carried out in triplicate. Flasks were inoculated with small quantities of algae $\left(\sim 5-10 \times 10^{6}\right.$ cells. $\left.L^{-1}\right)$ or cyanobacteria $\left(\sim 20 \times 10^{6}\right.$ cells.L $L^{-1}$, corresponding to $\sim 20$ fluorescence units). Different initial cell densities were chosen to standardize initial biomass across the differently sized organisms. The OECD-recommended test duration of $72 \mathrm{~h}$ was extended to $96 \mathrm{~h}(=4 \mathrm{~d})$, to allow more time for plant-algae/cyanobacteria interactions to develop, while growth of tests organisms in plant-devoid control flasks was still expected to be exponential. Algal and cyanobacterial densities were determined daily for each flask, except for day $1\left(d_{1}\right)$ in September, when determination was prevented by technical problems. $R$. subcapitata and F. pelliculosa densities were determined using an electronic particle counter (Beckman Coulter Multisizer ${ }^{\circledR}$ M3, Miami, FL). This technique was not appropriate for small-sized S. leopoliensis because of interference from particulate material and possible sprig-associated bacteria. $S$. leopoliensis density was determined as DCMU-enhanced chlorophyll fluorescence (measured at $665 \mathrm{~nm}$ after excitation at $530 \mathrm{~nm}$ ) using a Micropore Cytofluor plate scanner.

Field-collected $C$. demersum and $E$. canadensis sprigs were stored overnight in the dark at $4{ }^{\circ} \mathrm{C}$ before each trial. The short acclimatization period was dictated by the need to use freshly collected plants to preserve sprig natural conditions at the time of collection. The next day, healthy, apical $\sim 6-8-\mathrm{cm}$ long sprigs were acclimated to laboratory temperature and light, rinsed, their biomass individually determined as wet weight on an electronic precision balance (instrument resolution $=0.1 \mathrm{mg}$ ) following Lombardo and Cooke's (2003) methods, and placed in the flasks according to the scheme in Appendix Figure A-2. Final sprig biomass was determined as for initial biomass. Changes in sprig biomass were normalized as percent departures from initial values. Changes $>100 \%$ represented net biomass accrual, and changes $<100 \%$ net biomass loss.

Flasks were randomly placed on a shaking table under continuous illumination from white fluorescent lamps providing $70 \mu \mathrm{E} \cdot \mathrm{m}^{-2} \cdot \mathrm{s}^{-1}$ of effective photosynthetic radiation. Such a value allows for rapid exponential growth of test organisms (OECD, 2011), is not limiting for plants (Sand-Jensen and Madsen, 1991) or algae (Jørgensen, 1969; Geider et al., 1986), and prevents photorespiration (e.g., Bouterfas et al., 2002). Final $\left(\mathrm{d}_{4}\right)$ densities of test organisms was exponential in all control flasks except in $S$. leopoliensis June flasks. However, final $S$. leopoliensis density in such flasks was safely above the required minimum $16 \times$ increase from initial values for the test to be considered valid (OECD, 2011), and results from this trial were retained. The unobstructed light source, small sprig:flask size and continuous stirring allowed to exclude the involvement of shading and cell/particle trapping within the physical "filter" of sprig stems and leaves, as also argued for similar small-scale, laboratory setups (e.g., Lürling et al., 2006). The observed plant-algae/cyanobacteria interaction patterns therefore could be ascribed to the two remaining known possible mechanisms: allelopathy and/or competition for nutrients.

Nutrient dynamics were quantified in one subset of flasks for each monthly trial. Total dissolved phosphorus (TDP) and total dissolved nitrogen concentrations (TDN) at $d_{4}$ were determined in R. subcapitata flasks applying Faafeng and Hessen's (1993) methods to filtered 
water samples (filter pore size $=0.45 \mu \mathrm{m}$ ). Nutrient determinations were limited to $R$. subcapitata flasks after TDP and TDN concentrations in R. subcapitata and F. pelliculosa flasks were found to be statistically similar in June (two-tailed $t$-tests: $t_{\mathrm{TDP}}=0.206, p=0.839$; $t_{\mathrm{TDN}}=0.628, p=0.539 ; n_{\mathrm{R} . \text { sub }}=n_{\text {F.pel }}=9$ and $d f=16$ for both). Sprig net nutrient $(\mathrm{N}, \mathrm{P})$ uptake rates were estimated using Hilt and Lombardo's (2010) concentration-based mass balance approach. Because of the force majeure coarse estimate and impossibility to apply replicate-based statistics, nutrient uptake estimates are not treated in detail. An outline of the estimation method is reported in Appendix.

Because potential allelochemicals were not identified, allelopathy was assumed to be a factor when algal growth inhibition occurred in the absence of nutrient effects (Hilt and Lombardo, 2010). Even when nutrient effects were observed, sensu strictu competition for nutrients was unlikely, due to the overall high nutrient availability. Therefore, as in Hilt and Lombardo (2010), a more general nutrient mediation or influence (i.e., sensu latu competition for nutrients) in plant-algae interactions was assumed to occur in such cases.

\section{> IN SITU PHYTOPLANKTON SURVEY}

Phytoplankton at the sites and times of sprig collection was analyzed for biovolume and taxonomic composition. Two 100-mL grab water samples (depth $\sim 20 \mathrm{~cm}$ ) were collected inside (or above if macrophyte stands were too dense) and just outside macrophyte stands. Distance between inside and outside grab samples was $\sim 2-5 \mathrm{~m}$, depending on habitat conditions (the shorter and more distinct the habitat transition, the shorter the distance between samples). Care was taken to minimize water disturbance to avoid inclusion of epiphyton from nearby plants.

Phytoplankton samples were immediately fixed in acidified Lugol's solution (Olrik et al., 1998). Taxonomic analysis was carried out at the lowest possible level, usually genus or species. Phytoplankton biovolume was estimated from cell densities (calculated according to Olrik et al., 1998). In situ phytoplankton sampling was carried out without replication after variance for June biovolume triplicates was deemed sufficiently small $\left(\chi^{2} \leqslant 3.71\right.$ and $p \geqslant 0.16$ for $\chi^{2}$ tests of variance with $H_{0}=$ variance $\leqslant 10 \%$ of average, for total phytoplankton and all major classes; $d f=2$ for each test).

Additional samples were collected for nutrient (TDP, TDN) concentration determination, immediately stored in ice and processed within $24 \mathrm{~h}$ from collection following the same procedure as for laboratory nutrient samples. Water transparency was measured in situ as Secchi depth. Nutrient concentrations and water transparency were determined as single samples or measurements at each subsite (inside and outside macrophyte stands) at each visit. Field sampling and related sprig collection were carried out under "dry weather" conditions (i.e., at least $72 \mathrm{~h}$ after a major storm) to avoid direct influence of runoff (e.g., increased water turbulence and nutrient/silt inputs) on collected samples.

\section{> STATISTICAL ANALYSIS}

Differences among laboratory experimental conditions were tested within each monthly trial using repeated-measures ANOVAs followed by Tukey's honestly significant difference (HSD) multiple-comparison tests in case of significant plant effects within each experimental day. The HSD test effectively controls the family-wise Type I error to no more than the nominal level (Quinn and Keough, 2002), with no need for Bonferroni corrections. Because of the forced absence of within-month replication, two- or paired-sample two-tailed $t$-tests were run for specific subsets of field data.

Data departure from normality could not be assessed quantitatively because of small sample size ( $n=3)$; however, data were likely not normally distributed. In situ phytoplankton data were square-root-transformed using Anscombe's formula $\left[x^{\prime}=\sqrt{x+3 / 8}\right]$, percent relative abundances were arcsine-transformed using Anscombe's formula $\left[x^{\prime}=\arcsin \sqrt{(x+3 / 8) \times 4 / 7}\right]$, 
and all other data were log-transformed using Bartlett's formula $\left[x^{\prime}=\log _{10}(x+1)\right]$ before statistical analysis (Zar, 2009). Correlations and regressions were performed for selected datasets using original, untransformed data because of analysis reliability when nonnormality is not extreme (Zar, 2009). Best-fitting curves are reported for simple correlations and regressions; multiple correlations remained linear.

Significance threshold for all tests was set a priori at $p \leqslant 0.05$. Statistical analyses were performed with Addinsoft ${ }^{\circledR}$ XLSTAT $^{\circledR}$ v. 2012.6.09 and employed a gradient of standard $(p \leqslant$ $0.05)$ to strong $(p \leqslant 0.01)$ and very strong $(p \leqslant 0.0001)$ significance levels.

In situ phytoplankton assemblages were compared by means of Whittaker's (1952) similarity index expressed in percent format (\%PSC):

$$
\% \mathrm{PSC}=100 \times\left\{1-1 / 2\left[\sum_{h}\left|\frac{n_{A}}{N_{A}}-\frac{n_{B}}{N_{B}}\right|\right]\right\}
$$

where $n_{A}$ = biovolume of taxon $\mathrm{i}$ in assemblage (sample) $\mathrm{A}, n_{B}=$ biovolume of taxon $\mathrm{i}$ in assemblage $B$, and $N_{A}$ and $N_{B}$ = total biovolumes in assemblages $A$ and $B$ respectively, each containing $h$ taxa. Two assemblages with identical species distribution have \%PSC $=100 \%$.

\section{RESULTS}

\section{> LABORATORY EXPERIMENTS}

Growth of $R$. subcapitata and F. pelliculosa was significantly lower than controls in sprigcontaining flasks in June and August, except in E. canadensis flasks in June, while controlvs.-plant differences in algal growth were nonsignificant in July and September (Figure 1; Appendix Table A-I). Growth of $R$. subcapitata remained (quasi) exponential through $\mathrm{d}_{4}$ in all flasks, while $F$. pelliculosa appeared to reach a growth peak or plateau at $d_{3}$ (Figure 1). Despite always having reached $d_{4}$ density at $>16 \times$ as required by the OECD (2011) test, S. leopoliensis did not enter a truly exponential growth in June and September control flasks (Figure 1). Except in September, growth of S. leopoliensis never entered the exponential phase in C. demersum flasks either, while cyanobacterial densities reached significant (HSD separations at $p \leqslant 0.05$ : Appendix Table A-I) higher-than-control levels in $E$. canadensis flasks starting from $\mathrm{d}_{1}$ or $\mathrm{d}_{2}$ in all monthly trials (Figure 1). The only instance of significant lower-than-control $S$. leopoliensis $\mathrm{d}_{4}$ density in $E$. canadensis flasks was in August, following an apparent progressive decline in cell density after a significant (HSD: $p \leqslant 0.05$ ) "jump start" on $d_{1}$ (Figure 1).

$C$. demersum sprigs grew significantly in June in all flasks, while growth was lower and more variable in July and August, and became negative in September (Figure 2; Appendix Table A-II). The only instance of significant net growth for $E$. canadensis sprigs was in $R$. subcapitata flasks in August (Figure 2); however, when data from all algal/cyanobacterial flasks were pooled, $E$. canadensis as a whole did not grow significantly in August (Table I). Though growth of $C$. demersum remained nonsignificant in F. pelliculosa and $S$. leopoliensis presence in August (Figure 2), C. demersum sprigs in general did grow in August (Table I). C. demersum consistently grew more or lost less biomass than E. canadensis, except in August, when growth patterns were similar ( $p=0.282$ for the between-species comparison in Figure 2). However, C. demersum never lost biomass except in September, and E. canadensis always lost biomass except in August (Table I). Average biomass loss of E. canadensis in September was twice as much as $C$. demersum 's (Table I).

When data from all monthly trials were pooled, chlorophyte or diatom growth was negatively correlated with sprig growth in an exponential fashion (Figure 3). The plant-cell growth relationship remained closer for $R$. subcapitata than for $F$. pelliculosa (qualitative comparison of $r^{2}$ and $p$ values in Figure 3). Though still following negative exponential paths, the trends for S. leopoliensis remained not significant $\left(r^{2} \leqslant 0.239, p \geqslant 0.107 ; n\right.$ and $d f$ as in Figure 3).

Final $R$. subcapitata cell density in macrophyte absence was positively correlated with TDP but not with TDN concentration, while growth in sprig presence was correlated with concentrations of both nutrients (Figure 4). Final $\left(\mathrm{d}_{4}\right)$ nutrient (TDP, TDN) concentrations in $R$. 

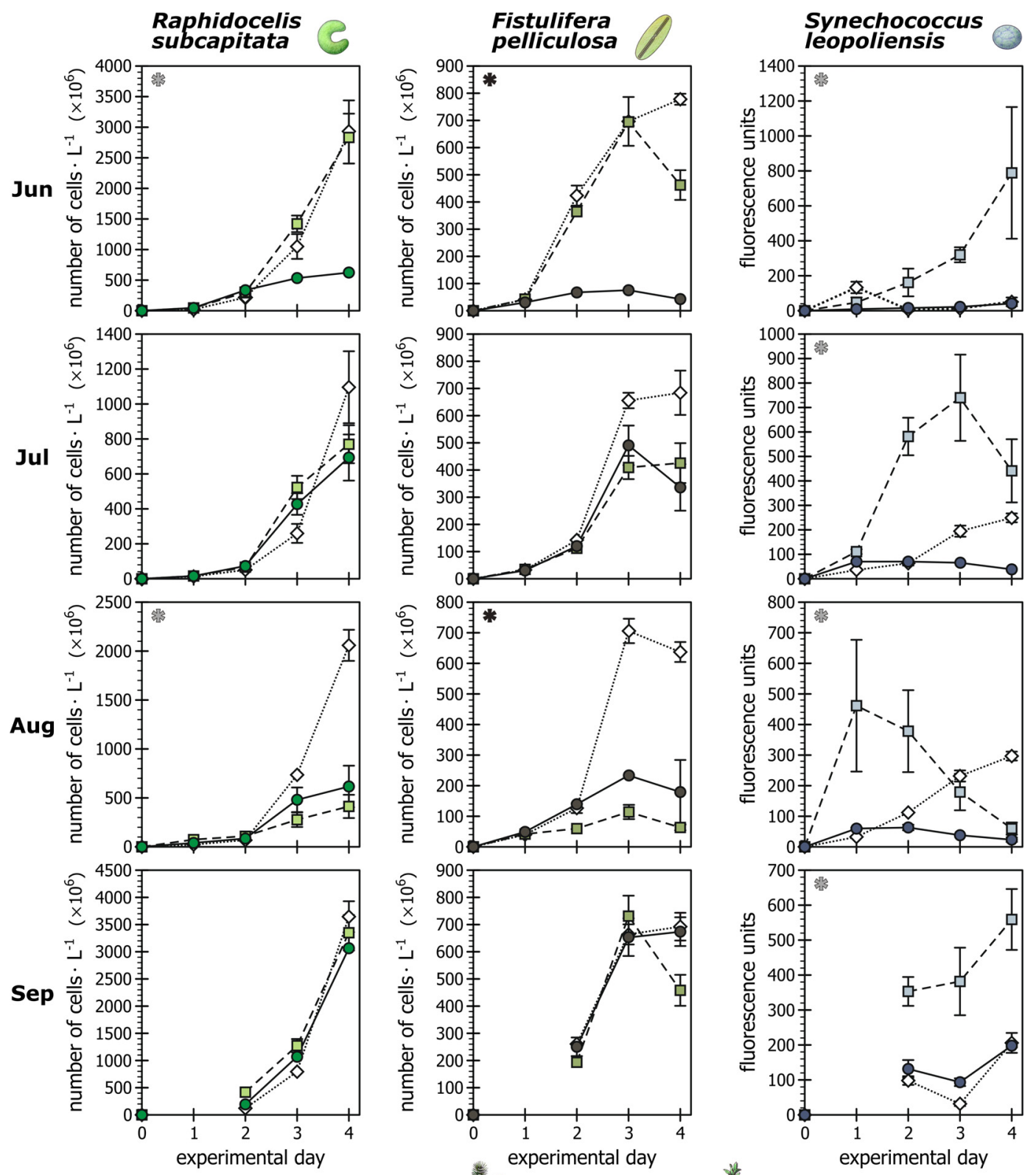

Ceratophyllum demersum * - * Elodea canadensis

.. $\diamond$ no plants

Figure 1

Density of algae and cyanobacteria (as cell counts or fluorescence) in laboratory flasks in the presence or absence of $C$. demersum or E. canadensis sprigs; average \pm standard error ( $n=3$ for each). Asterisks in each panel represent the significance level of differences in plant treatments for repeated-measures ANOVAs ( $p \leqslant 0.05 ; * p \leqslant 0.01 ; * p \leqslant 0.0001$; no asterisk: n.s.); differences in time were always significant at $p \leqslant 0.0001$. Complete ANOVA and accompanying HSD test results are in Appendix Table A-I. Please note the different $y$ axis scales.

subcapitata flasks were always significantly lower than initial conditions in sprig absence and in C. demersum presence $\left(t \geqslant 2.788, p \leqslant 0.049\right.$ for initial-vs. -final $t$-tests with $n_{\text {init }}=n_{\text {fin }}=3$ and $d f=4)$. TDN concentration in $E$. canadensis presence remained significantly lower than in no-plant flasks until September $(t \geqslant 3.600, p \leqslant 0.023)$, when it surged to significantly higher-than-control values $(t=-4.613, p=0.010)$ along with TDP concentration ( $t=-6.989$, $p=0.002)$. TP concentration in $E$. canadensis presence was lower than in control flasks only in July $(t=4.736, p=0.009)$. 


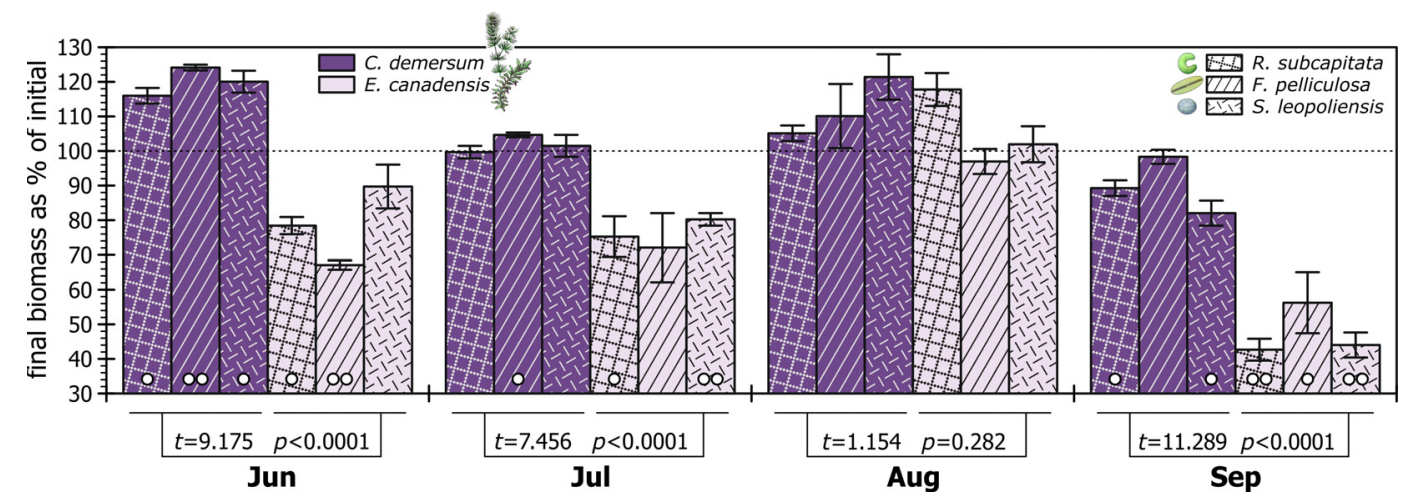

Figure 2

Net change in sprig live biomass (wet weight) for C. demersum or $E$. canadensis at $d_{4}$ in laboratory flasks in algal/cyanobacterial presence; average \pm standard error $(n=3$ for each). Horizontal dotted line represents no change; biomass gain is above and biomass loss below the line. White dots represent significant biomass gain or loss according to paired-sample $t$-tests ( $n=3$ and $d f=4$ for each), with significance thresholds at $p \leqslant 0.05(\bigcirc), p \leqslant 0.01(\bigcirc \bigcirc)$, and $p \leqslant 0.0001(\bigcirc \bigcirc \bigcirc)$; complete results are in Table A-II. Two-tailed $t$-tests within each month $\left(n_{\mathrm{C} . \mathrm{dem}}=n_{\mathrm{E} . \mathrm{can}}=9\right.$; $\left.d f=16\right)$ compare $\mathrm{C}$. demersum-vs.E. canadensis biomass changes regardless of test organism.

\section{Table I}

Net changes in sprig biomass during the 4- $d$ flask experiment by month (average \pm standard error), with final biomass expressed as percent departure from initial condition (initial biomass $=100 \%$, biomass accrual $>100 \%$ and biomass loss $<100 \%$ ), and associated paired-sample two-tailed $t$-tests (performed on arcsine-transformed percent data), pooling data across phytoplankton taxa. For each comparison, $n=9$ and $d f=8$. Negative $t$ values represent biomass loss from initial condition, with significant biomass accrual or loss for $p \leqslant 0.05$. Significance levels are highlighted with $\bigcirc(p \leqslant 0.05), \bigcirc \bigcirc(p \leqslant 0.01)$, and $\bigcirc \bigcirc \bigcirc(p \leqslant 0.0001)$.

\begin{tabular}{|c|c|c|c|c|}
\cline { 2 - 5 } \multicolumn{1}{c|}{} & \multicolumn{2}{c|}{ Ceratophyllum demersum } & \multicolumn{2}{c|}{ Elodea canadensis } \\
\cline { 2 - 5 } \multicolumn{1}{c|}{} & $\begin{array}{c}\text { Final biomass } \\
\text { as } \% \text { of initial }\end{array}$ & $\begin{array}{c}\text { Initial-vs.-final } \\
\text { comparison }\end{array}$ & $\begin{array}{c}\text { Final biomass } \\
\text { as \% of initial }\end{array}$ & $\begin{array}{c}\text { Initial-vs.-final } \\
\text { comparison }\end{array}$ \\
\hline Jun & $120.1 \pm 1.6$ & $\begin{array}{c}t=10.577 \\
p<0.0001000\end{array}$ & $78.4 \pm 3.8$ & $\begin{array}{c}t=-5.808 \\
p=0.000400\end{array}$ \\
\hline Jul & $101.9 \pm 1.3$ & $\begin{array}{r}t=1.541 \\
p=0.162\end{array}$ & $75.8 \pm 3.6$ & $\begin{array}{c}t=-7.311 \\
p<0.0001000\end{array}$ \\
\hline Aug & $112.2 \pm 4.1$ & $\begin{array}{r}t=2.841 \\
p=0.022\end{array}$ & $105.6 \pm 3.8$ & $\begin{array}{c}t=1.538 \\
p=0.163\end{array}$ \\
\hline Sep & $90.0 \pm 2.7$ & $\begin{array}{r}t=-3.739 \\
p=0.006\end{array}$ & $47.8 \pm 3.6$ & $\begin{array}{c}t=-15.281 \\
p<0.0001000\end{array}$ \\
\hline
\end{tabular}

The strength of TDP-growth relationship was similar in sprig-absent controls and in C. demersum- and E. canadensis-present flasks $\left[\chi_{P}^{2}=3.467, p=0.177\right.$ for Paul's (1988) multiple comparison of $r^{2}$ values; details in Appendix Table A-III]. However, the slopes for the TDP-growth correlations in Figure 4 were significantly different $(p<0.0001)$ in $C$. demersum and E. canadensis presence (Appendix Table A-III). The TDN-growth relationship was significantly highest in $C$. demersum flasks, followed by $E$. canadensis and control flasks, in this order $\left[\chi_{P}^{2}=17.131, p=0.0002\right.$ for Paul's (1988) multiple comparison of $r^{2}$ values followed by Zar's (2009) Tukey-type test: Appendix Table A-III]. The three slopes for the TDN-growth correlations also were significantly different (Appendix Table A-III). The closest $R$. subcapitata-nutrient relationship occurred for TDN in the presence of $C$. demersum $\left(r_{\mathrm{TDN}-\mathrm{C} . \mathrm{dem}}^{2}=0.935\right)$ (Figure 4). The strength of the $R$. subcapitata - TDN correlation in $C$. demersum flasks was significantly higher than the corresponding $R$. subcapitata -TDP correlation $(Z=2.882, p=0.004$ : Appendix Table A-III), while the opposite occurred in control flasks 

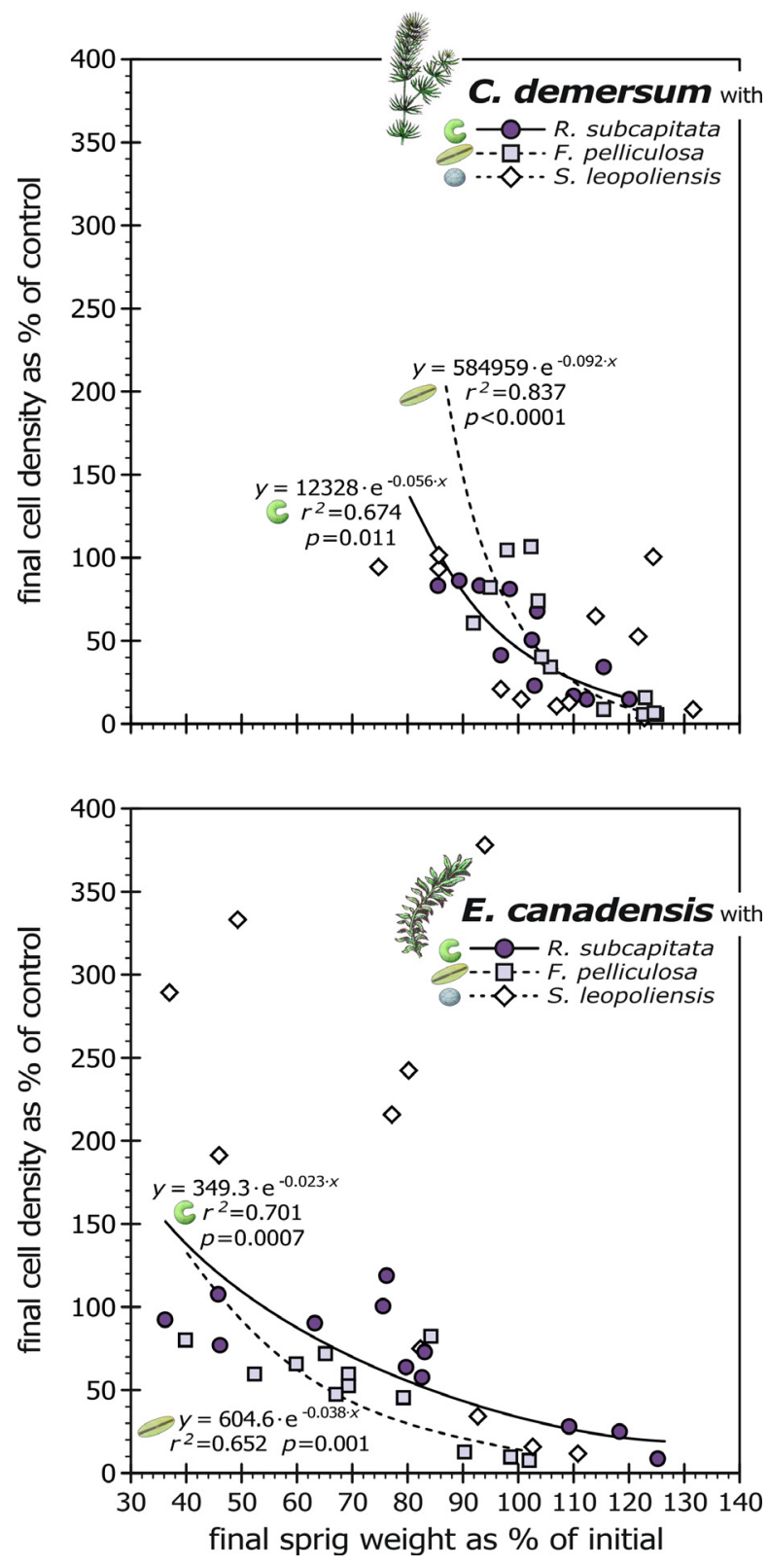

Figure 3

Relationships between algal/cyanobacterial density (as percent of corresponding controls; $100 \%=$ same as in controls) and sprig biomass change (as percent of initial live weight; $100 \%=$ no change) in C. demersum- or E. canadensis-present flasks at $d_{4}$. For all regressions, $n=12$ and $d f=10$. Two E. canadensis-S. leopoliensis outliers (final cell density $>400 \%$ of control) are excluded from graphical representation but included in regression analysis. S. leopoliensis regressions were not significant $\left(r_{\mathrm{C} . \mathrm{dem}}^{2}=0.239, p=0.107 ; r_{\mathrm{E} . \mathrm{can}}^{2}=0.153, p=0.209\right)$.

$(Z=3.353, p=0.0008)$. The TDP and TDN correlations had similar strength in $E$. canadensis flasks $(Z=0.929, p=0.353$ : Appendix Table A-III).

Except for TDP in $C$. demersum flasks, final nutrient concentrations and sprig growth were inversely correlated (Table II). Daily sprig (fresh weight) nutrient uptake rates remained in the $-40-6 \mu \mathrm{g} \cdot \mathrm{g}^{-1} \cdot \mathrm{d}^{-1}$ range for $\mathrm{P}$ and in the $-270-104 \mu \mathrm{g} \cdot \mathrm{g}^{-1} \cdot \mathrm{d}^{-1}$ range for $\mathrm{N}$ (Appendix Table A-IV). Estimated daily nutrient uptake rates were always positive for $C$. demersum, except in July when sprigs leaked $1.1 \mu \mathrm{g} \cdot \mathrm{P} \cdot \mathrm{g}^{-1} \cdot \mathrm{d}^{-1}$. Phosphorus uptake rates were always negative for $E$. canadensis except in August, when sprigs sequestered $3.8 \mu \mathrm{g} \cdot \mathrm{P} \cdot \mathrm{g}^{-1} \cdot \mathrm{d}^{-1}$, but $\mathrm{N}$ uptake rates remained positive until September, when E. canadensis leaked $269.3 \mu \mathrm{g} \cdot \mathrm{N} \cdot \mathrm{g}^{-1} \cdot \mathrm{d}^{-1}$ 

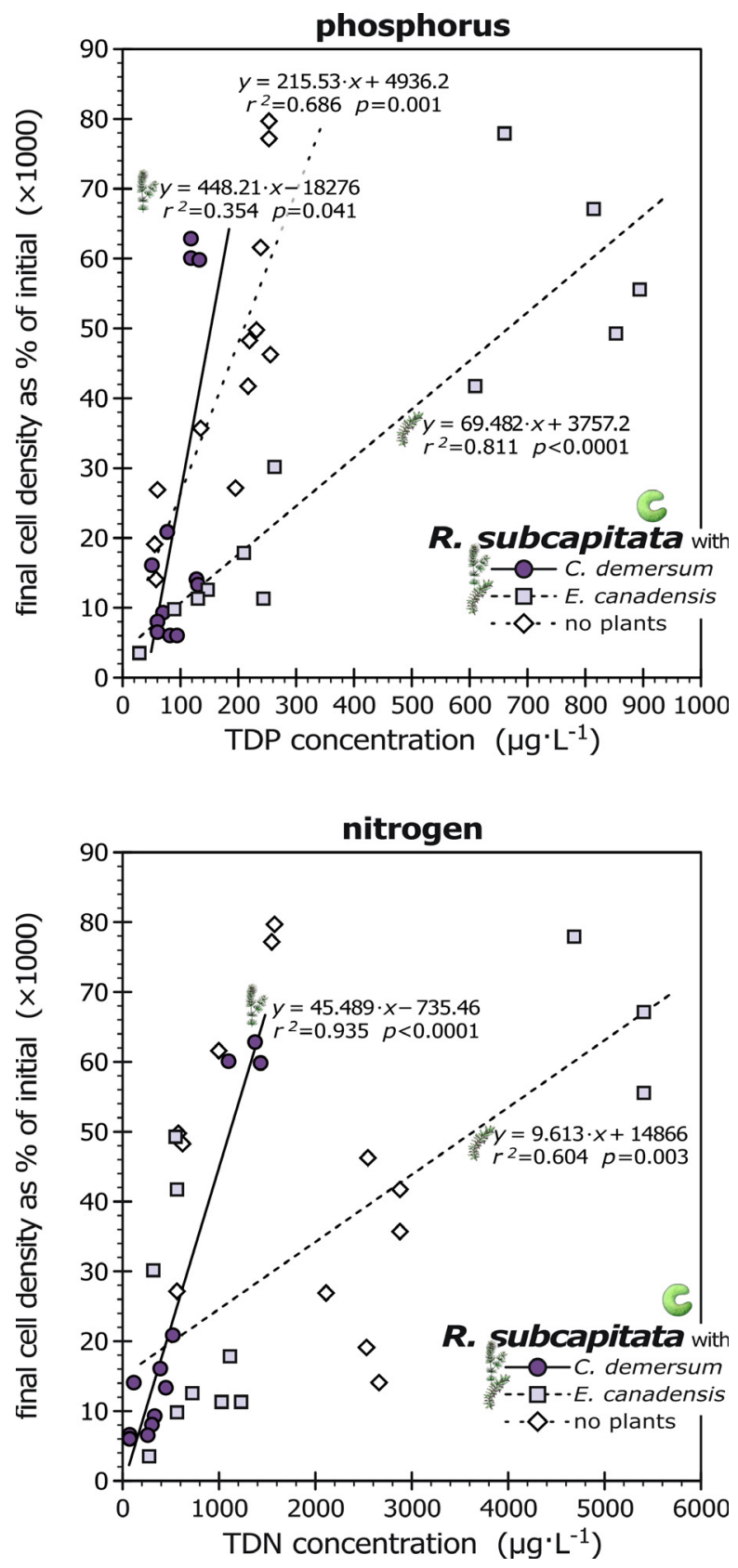

\section{Figure 4}

Final R. subcapitata density (as percent of initial; $100 \%=$ no change) in relation to $d_{4}$-nutrient concentrations in C. demersum-, E. canadensis-, or plant-devoid laboratory flasks. For all regressions, $n=12$ and $d f=10$. All regressions were significant $(p \leqslant 0.05)$ except for the TDN relationship in plant absence $\left(r^{2}=0.143, p=0.225\right)$.

(Appendix Table A-IV). Significant inhibition of $R$. subcapitata growth occurred only when sprig nutrient uptake rates were positive for both $\mathrm{P}$ and $\mathrm{N}$ (Appendix Table A-IV). Estimated daily nutrient uptake rates were correlated with sprig growth for $E$. canadensis (multiple linear correlation: $r^{2}=0.740, d f=9, p=0.002: \%$ change in biomass $=91.58-0.76 \times$ TDP $-7.12 \times$ $10^{-2} \times$ TDN, with nutrient uptake rates as $\left.\mu \mathrm{g} \cdot \mathrm{g}^{-1} \cdot \mathrm{d}^{-1}\right)$ but not for $C$. demersum $\left(r^{2}=0.022\right.$, $d f=9, p=0.903)$. 


\section{Table II}

Correlations between net sprig growth and total dissolved phosphorus or total dissolved nitrogen concentrations (TDP and TDN) at $t_{\mathrm{F}}$ in C. demersum- or E. canadensis-containing flasks (June-September data pooled; $n=12$ and $d f=11$ for all correlations). Net sprig growth as percent departure from initial biomass; nutrient concentrations in $\mu g \cdot L^{-1}$. Correlations are linear (lin) or exponential (exp); negative $r$ values represent negative slopes for either correlation type. Significance levels are highlighted with $\bigcirc$ $(p \leqslant 0.05), \bigcirc \bigcirc(p \leqslant 0.01)$, and $\bigcirc \bigcirc \bigcirc(p \leqslant 0.0001)$.

\begin{tabular}{|c|c|c|c|c|c|c|}
\cline { 2 - 7 } \multicolumn{1}{c|}{} & \multicolumn{3}{c|}{ C. demersum } & \multicolumn{3}{c|}{ E. canadensis } \\
\cline { 2 - 7 } \multicolumn{1}{c|}{} & type & $r$ & $p$ & type & $r$ & $p$ \\
\hline TDP & lin & -0.209 & 0.495 & $\operatorname{lin}$ & -0.755 & 0.003 \\
\hline TDN & lin & -0.839 & 0.000500 & $\exp$ & -0.864 & 0.000200 \\
\hline
\end{tabular}

\section{$>$ IN SITU PHYTOPLANKTON SURVEY}

In situ total phytoplankton biovolume fluctuated widely in $E$. canadensis-dominated Østensjøvatn (Figure 5), but biovolume remained significantly lower inside than outside the $E$. canadensis stand (paired-sample two-tailed $t$-test on pooled monthly data: $t=-3.321, d f=3$, $p=0.045$; Appendix Table A-V). Total phytoplankton biovolume in C. demersum-dominated Spiradammen remained at low values throughout the sampling period (Figure 5). Total phytoplankton biovolume was significantly lower in Spiradammen (paired-sample, two-tailed $t$-test on pooled monthly data: $t=5.471, p=0.0009, n=8$ and $d f=7$ ).

Biovolumes of major phytoplankton groups were similar inside and outside macrophyte stands (Appendix Table A-V). Cyanobacterial, diatom, and cryptophyte biovolumes were significantly lower in Spiradammen (paired-sample, two-tailed $t$-tests on pooled monthly data: $t_{\text {cyano }}=2.949, p=0.021 ; t_{\text {diatom }}=8.882, p<0.0001 ; t_{\text {crypto }}=4.373, p=0.003 ; n=8$ and $d f=7$ for all); differences for other groups remained not significant $(p>0.05)$.

Total number of phytoplankton taxa was similar inside and outside macrophyte stands (paired-sample, two-tailed $t$-tests on pooled monthly data: $t_{\mathrm{Spi}}=0.507, p=0.647$; $t_{\text {Øst }}=$ $0.269, p=0.805 ; n=4$ and $d f=3$ for both), with most taxa common to both subhabitats in either lake (Figure 5). Number of phytoplankton taxa was significantly higher in Østensjøvatn (paired-sample, two-tailed $t$-test on pooled monthly data: $t=6.289, p=0.0004, n=8$ and $d f=7)$. Inside- and outside-stand assemblages within each lake had similar taxonomic structures, with \%PSC never $<50 \%$ in either lake (Figure 5).

The cryptophyte Rhodomonas lacustris was the only major phytoplankton taxon common to the two lakes. $R$. lacustris codominated the Spiradammen phytoplankton with the chlorophytes Raphidocelis subcapitata and Botryococcus braunii. The only cyanobacterium present in appreciable density in Spiradammen was Woronichinia naegeliana ( 4-10\% of total biovolume in June and July). Østensjøvatn phytoplankton was codominated by several Dolichospermum (=Anabaena) species and by a diverse assemblage of diatoms (Diatoma tenuis, Asterionella formosa, Fragilaria spp., Stephanodiscus hantzschii, Aulacoseira spp.). Phytoplankton maxima in Østensjøvatn were dominated by Dolichospermum lemmermanni ( $50 \%$ of June total biovolume) and $D$. planctonicum ( $60-70 \%$ of August total biovolume). The cyanobacterium Microcystis was observed only in Østensjøvatn, where it remained at low numbers ( $0-5 \%$ by volume). Relative abundance of all common phytoplankton taxa was similar inside and outside macrophyte beds in either lake (Appendix Table A-VI).

Water transparency followed the same temporal trend in both lakes, with qualitatively (no replication) lower transparency inside macrophyte stands in June followed by equal insidevs.-outside values afterwards (Figure 5). Outside-stand Secchi depth in Spiradammen was always to bottom (sediment patches were always visible from the boat) from July on. Water transparency was significantly higher in Spiradammen (paired-sample, two-tailed $t$-test on pooled monthly data: $t=3.628, p=0.008, n=8$ and $d f=7$ ). In-lake nutrient concentrations were always higher in Østensjøvatn (Figure 5), resulting in a significant between-lake difference (paired-sample, two-tailed $t$-tests on pooled monthly data: $t_{\mathrm{TDP}}=4.286, p=0.004$; $t_{\mathrm{TDN}}=4.769, p=0.002 ; n=8$ and $d f=7$ for both). Total phytoplankton biovolume was not correlated with TDP or TDN concentrations in Spiradammen, but it was in Østensjøvatn (Table III). 

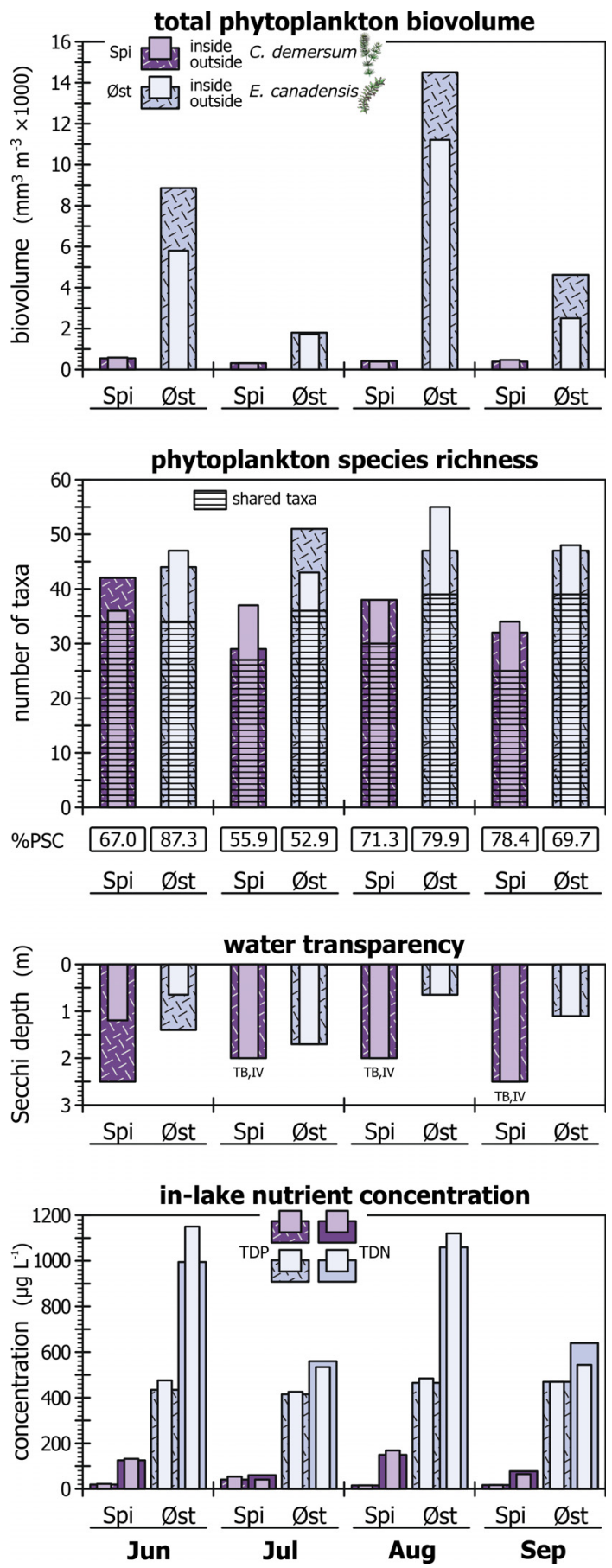

\section{Figure 5}

Comparison of inside- vs. outside-macrophyte stand phytoplankton (top panels) and physico-chemical conditions (bottom panels) in C. demersum-dominated Spiradammen (Spi) and E. canadensisdominated Østensjøvatn (Øst) at the time of macrophyte sprig collection. The number of taxa common to inside and corresponding outside phytoplankton assemblages is represented by horizontal line shading. Taxonomic similarity of inside-vs.-outside stand phytoplankton assemblages is quantified by the \%PSC index (0\% = no taxonomic overlap; $100 \%$ = complete overlap). TB = Secchi depth to bottom; IV = Secchi disc disappeared in the vegetation (sediments visible in unvegetated patches nearby). For all variables, $n=1$ within each sampling month and subhabitat (inside or outside macrophyte stands). 


\section{Table III}

Correlations between total phytoplankton biovolume (in $\mathrm{mm}^{3} \cdot \mathrm{m}^{-3}$ ) and total dissolved phosphorus or total dissolved nitrogen concentrations (TDP and TDN, in $\mu \mathrm{g} \cdot \mathrm{L}^{-1}$ ) inside and outside the C. demersum (Spiradammen) or E. canadensis stands (Østensjøvatn) that supplied sprigs for laboratory experiments (June-September data pooled; $n=4$ and $d f=3$ for all correlations). Correlations are linear (lin) or exponential (exp); negative $r$ values represent negative slopes. Significance levels are highlighted with $\bigcirc$ ( $p \leqslant 0.05), \bigcirc \bigcirc(p \leqslant 0.01)$, and $\bigcirc \bigcirc(p \leqslant 0.0001)$.

\begin{tabular}{|c|c|c|c|c|c|c|}
\cline { 2 - 7 } \multicolumn{1}{c|}{} & \multicolumn{6}{c|}{ Spiradammen } \\
\cline { 2 - 7 } \multicolumn{1}{c|}{} & \multicolumn{2}{|c|}{ Inside C. demersum } & \multicolumn{2}{c|}{ Outside C. demersum } \\
\cline { 2 - 7 } & Type & $r$ & $p$ & Type & $r$ & $p$ \\
\hline TDP & lin & -0.506 & 0.494 & lin & -0.663 & 0.337 \\
\hline TDN & lin & 0.467 & 0.533 & lin & 0.197 & 0.803 \\
\hline
\end{tabular}

\begin{tabular}{|c|c|c|c|c|c|c|}
\cline { 2 - 7 } \multicolumn{1}{c|}{} & \multicolumn{6}{c|}{ Ostensjovath } \\
\cline { 2 - 7 } \multicolumn{1}{c|}{} & \multicolumn{2}{|c|}{ Inside E. canadensis } & \multicolumn{2}{c|}{ Outside E. canadensis } \\
\cline { 2 - 7 } & Type & $r$ & $p$ & Type & $r$ & $p$ \\
\hline TDP & $\exp$ & 0.997 & $0.0002 \bigcirc 0$ & $\exp$ & 0.964 & 0.008 \\
\hline TDN & $\exp$ & 0.919 & $0.027^{\circ}$ & $\exp$ & 0.943 & 0.016 \\
\hline
\end{tabular}

\section{DISCUSSION}

\section{> LABORATORY EXPERIMENTS}

Both $C$. demersum and $E$. canadensis exhibited some ability to suppress algal growth in laboratory microcosms until late August (Figure 1), consistent with earlier laboratory observations (Gross et al., 2003; Lürling et al., 2006). Except in September, S. leopoliensis never grew in C. demersum flasks (Figure 1), though cyanobacterial inhibition by $C$. demersum remained not significant in June due to uncharacteristic low cyanobacterial growth in control flasks (Appendix Table A-I). Growth of S. leopoliensis instead was almost always enhanced in $E$. canadensis presence (Figure 1; Appendix Table A-I). Although our quantitative (Figure 1) and qualitative results (consistent observations of crystal-clear medium in $C$. demersum flasks through $\mathrm{d}_{4}$ ) align with earlier observations of cyanobacterial growth inhibition by C. demersum (Wium-Andersen, 1987; Jasser, 1995; Nakai et al., 1999; Gross et al., 2003; Hilt and Gross, 2008), cyanobacterial enhancement by E. canadensis does not (Erhard and Gross, 2006; Hilt, 2006). Though overlapping on some aspects, seasonal dynamics in plant-algae and plant-cyanobacteria interactions varied with macrophyte species (Figure 1), suggesting that the observed patterns may have been determined by a combination of species-specific plant-algae interactions and seasonal changes in macrophyte condition, as also argued elsewhere (Jasser, 1995; Hilt et al., 2006).

The experimental setup restricts the list of the possible mechanisms involved in the observed plant-algae interactions to allelopathy and competition for nutrients. Both $C$. demersum and E. canadensis produce allelochemicals capable of inhibiting algae and/or cyanobacteria (e.g., Gross et al., 2003; Erhard and Gross, 2006). Inhibition of algal photosynthetic pathways, a more direct measure of allelopathic interference than is population growth, was specifically observed in the physical presence of $C$. demersum (Körner and Nicklisch, 2002) and E. canadensis (Lürling et al., 2006), indicating that allelopathy by both $C$. demersum and $E$. canadensis could have been involved in mediating algal/cyanobacterial growth. However, the close association of $R$. subcapitata growth patterns with nutrient concentrations (Figure 4) strongly suggests nutrient (co)mediation of plant-chlorophyte interactions, as also found elsewhere (Lürling et al., 2006; Takeda et al., 2008; Hilt and Lombardo, 2010).

Regression analysis (Figure 4; Appendix Table A-III) suggests that $R$. subcapitata growth shifted from being $P$ regulated in sprig absence to being $P$ and $N$ coregulated in $E$. canadensis presence, and $\mathrm{N}$ regulated in $\mathrm{C}$. demersum presence. $\mathrm{N}$-mediated (co)regulation of phytoplankton patterns was observed also in situ in richly vegetated, C. demersum-dominated 
shallow Norwegian lakes (Mjelde and Faafeng, 1997), as well as in other, similar ecosystems (Gligora et al., 2007). Direct, positive R. subcapitata-nutrient relationships changing strength and/or direction in sprig presence (Figure 4 and Appendix Table A-III) and inverse sprignutrient relationships (Table II) suggest that nutrient dynamics in the flasks were driven by sprigs, as also found by Lürling et al. (2006) and Hilt and Lombardo (2010) in similar-purpose experiments, with growth of $R$. subcapitata being inhibited when growing sprigs were able to sequester nutrients, or enhanced when withering sprigs leaked nutrients into the medium.

However, estimated daily nutrient uptake rates by sprigs (Appendix Table A-IV) remained in the lower end of the known range from similar short-term experiments (e.g., Pelton et al., 1998; Lombardo and Cooke, 2003; Hilt and Lombardo, 2010), and quantitative inhibition of $R$. subcapitata apparently was not related to sprig nutrient uptakes (Appendix Table A-IV). Also, nutrient uptake rates were not correlated with $C$. demersum growth $\left(r^{2}=0.022, p=0.903\right)$, suggesting that the total quantity of nutrient removed by sprigs (with larger sprigs sequestering more nutrients) was the basis for the competition for nutrients between $C$. demersum and $R$. subcapitata. The significant sprig growth-nutrient uptake correlation for $E$. canadensis $\left(r^{2}=0.740, p=0.002\right)$ might have been driven by the wider range of biomass change for E. canadensis than $C$. demersum (Table I), suggesting that total nutrient removal (or leaking) might have been a nonnegligible cofactor in $E$. canadensis - $R$. subcapitata interactions as well. Despite the coarse estimation basis for nutrient uptake rates, our results suggest that sprigs inhibited algal growth by preemptively sequestering nutrients before algae can do so, supporting Craine et al. 's (2005) view of availability- and not uptake-driven competition for nutrients by plants. However, we cannot go beyond a generally stated involvement of competition for nutrients between macrophyte sprigs and algae, as 1. nutrient availability remained overall high; 2. nutrient effects cannot be separated satisfactorily with current methodology (e.g., Lürling et al., 2006; Gross et al., 2007); 3. both macrophyte and algal metabolism quickly adapt to substrate availability (Touchette and Burkholder, 2001; Collos et al., 2005); and 4. competition remains one of the most difficult ecological mechanisms to demonstrate empirically (e.g., Connell, 1980, 1983; Goldberg and Scheiner, 2001).

Absence of evidence of $R$. subcapitata nutrient-independent inhibition by $C$. demersum and absence of $R$. subcapitata growth inhibition by $C$. demersum exudates in a separate trial (unpublished data) support earlier observations of absence of allelopathy against chlorophytes by C. demersum (Jasser, 1995). The possible involvement of allelopathy by $E$. canadensis against $R$. subcapitata may be more difficult to extrapolate, as earlier investigations targeting E. canadensis allelopathy against chlorophytes yielded contradicting results (e.g., Erhard and Gross, 2006 vs. Lürling et al., 2006). The apparent absence of nutrient-independent action by $E$. canadensis against $R$. subcapitata may stem from species-specific insensitivity to $E$. canadensis potential allelochemicals by $R$. subcapitata (whose susceptibility to $E$. canadensis allelochemicals was not specifically tested in earlier studies), and/or from absent or insufficient allelochemical production by the Østensjøvatn population of E. canadensis. However, even if occurring, allelopathic inhibition of $R$. subcapitata by $E$. canadensis seems to have been subordinate to sensu latu competition for nutrients.

Growth patterns of $F$. pelliculosa closely resembled those of $R$. subcapitata. Though nutrient concentrations were not determined in F. pelliculosa flasks, similar chlorophyte and diatom growth patterns (Figure 1) and similar nutrient patterns in June R. subcapitata and F. pelliculosa flasks $(p \geqslant 0.539$ for $t$-tests) suggest the possibility of similar macrophytechlorophyte and macrophyte-diatom interactions, including an important role played by nutrients. Alternatively or additionally, F. pelliculosa may have been (co)limited by Si despite the high initial availability, as $\mathrm{d}_{4}$ collapses in F. pelliculosa density occurred in many flasks, regardless of sprig presence or absence (Figure 1). Such $d_{4}$ collapses were not observed in sprig-devoid $R$. subcapitata or S. leopoliensis flasks, which do not require Si for growth. Production of anti-diatom allelochemicals has been demonstrated for both $C$. demersum (Gross, $1995)$ and E. canadensis (Wium-Andersen, 1987), and diatoms seem to be particularly sensitive to allelochemicals from a number of macrophyte species (Gross, 1995; Körner and Nicklisch, 2002; Hilt, 2006), suggesting a possible involvement (albeit not quantifiable) of 
allelopathic inhibition of $F$. pelliculosa by $C$. demersum and/or E. canadensis. Weakly significant inhibition of $F$. pelliculosa but not $R$. subcapitata growth by $C$. demersum exudates in a separate experiment (T. Källqvist, unpublished data) supports the hypothesis of some involvement of allelopathy at least in $\mathrm{C}$. demersum-diatom interactions.

Regardless of the underlying mechanism(s), inhibition of chlorophyte and diatom growth occurred when sprigs accrued biomass (Figure 3). Takeda et al. (2011) similarly found strong inhibiting effects on the cyanobacterium Microcystis aeruginosa (Kützing) Kützing by extracts from Potamogeton pusillus L. taken from aquarium-cultivated plants which grew 10x during the assays, mirroring Gross's (2003) patterns for Myriophyllum spicatum L. In a rare study that quantified both plant and cyanobacterial growth response to coexistence, Li et al. (2009) found an inhibitory action of high-density Microcystis on the growth and photosynthetic rate of Ceratophyllum oryzetorum Kom., but also an inhibitory effect of actively growing C. oryzetorum on low-density Microcystis. The observed inverse relationship between sprig and algal growth (Figure 3) is consistent with higher nutrient and/or allelochemical concentrations in sites of new growth such as plant apical meristems or stem apices (Goulder and Boatman, 1971; Gross et al., 1996; Gross, 2000). In particular, Goulder and Boatman's (1971) observation of $\mathrm{N}$ accumulation in the apical $2 \mathrm{~cm}$ of field-collected $C$. demersum shoots is highly consistent with our own observation of sprig-driven, $\mathrm{N}$-dependent $R$. subcapitata growth in C. demersum flasks (Figure 3 and Appendix Table A-III). Thiébaut (2005) found higher ability to incorporate ambient $P$ by faster-growing plant species, including Elodea spp., similarly suggesting that plant ability to incorporate nutrients may be related to active growth.

Additionally, the observed temporal pattern in C. demersum net biomass change (Figure 2) mirrors in situ bimodal seasonal fluctuations in standing crop and metabolite production in temperate-climate natural C. demersum populations (Goulder, 1969; Pip and Philipp, 1990). Seasonal growth patterns for $E$. canadensis are highly variable, with late-starting populations seldom reaching full stand size and/or full-strength in situ phytoplankton inhibition (Ozimek and Balcerzak, 1976; Rørslett et al., 1986). Delayed, stunted E. canadensis growth was observed in Østensjøvatn and other nearby locations during the study year, probably because of a long period of low light availability associated with an unusual high spring water level during the study year (authors' personal observation). Allelochemical production seems to be closely associated with light availability (Gross, 2000, 2003; Hilt et al., 2006), possibly explaining E. canadensis's "poor performance" against target algae in our experiments. However, significant algal growth suppression by E. canadensis in August (Figure 1) was associated with a short-lived but evident in situ new growth from old, "brown" shoots, further supporting the hypothesis that inhibition of target algae, whether allelochemical- or nutrient-mediated, is strongly dependent on plant growth and/or health condition.

Different growth patterns for S. leopoliensis suggest different mechanisms in macrophytecyanobacteria than in macrophyte-algae interactions. Except for September, when sprig general inhibiting capabilities declined (Figure 1), growth patterns for S. leopoliensis did not follow seasonal trends, with significant inhibition in $C$. demersum presence in July and August and consistent enhancement in E. canadensis presence (Figure 1 and Appendix Table A-I). All C. demersum-containing June-August flasks remained clear through $\mathrm{d}_{4}$, and absence of significant S. leopoliensis inhibition in June was due more to uncharacteristic low growth in control flasks than to high growth in $C$. demersum flasks. Though nutrient concentrations in S. leopoliensis flasks were not determined, consistent absence of S. leopoliensis growth in $C$. demersum flasks suggests a looser association of cyanobacterial than algal growth with nutrient availability, and hence a likely nonnegligible (co)involvement of allelopathy by $C$. demersum against $S$. leopoliensis. This hypothesis is supported by demonstrated higher cyanobacterial (including Synechococcus) sensitivity to selective and/or strong allelopathic action by C. demersum and other macrophytes (Jasser, 1995; Gross et al., 1996; Nakai et al., 1999; Gross et al., 2003; Hilt and Lombardo, 2010). An apparent strong anticyanobacterial allelopathic effect of $C$. demersum may have prevented $S$. leopoliensis from developing, thus allowing $C$. demersum to take up the available nutrients at leisure and become established. Well-established, healthy $C$. demersum sprigs in turn may have rendered 
nutrients unavailable and/or produced full-strength anti-cyanobacterial allelochemicals, reinforcing sprig dominance.

S. leopoliensis enhancement in E. canadensis presence is counterintuitive. Although it is considered a "weak" allelopathic species (Hilt and Gross, 2008), E. canadensis produces allelochemicals that may be particularly effective against cyanobacteria, including some Synechococcus strains (Erhard and Gross, 2006). E. canadensis's variable seasonal or interannual growth (Ozimek and Balcerzak, 1976; Rørslett et al., 1986) may lead to variable allelopathic strength against algae and cyanobacteria, with higher effectiveness during periods of higher growth, mirroring Gross's (2000) seasonal observations for in situ M. spicatum subjected to varied epiphytic colonization. The isolated instance of eventual S. leopoliensis inhibition by $E$. canadensis occurred in August, i.e., at the only time of significant chlorophyte and diatom inhibition (Figure 1) coupled with sprig biomass retention (Figure 2 and Table I), supporting this hypothesis. At least some of the anti-cyanobacteria allelochemicals produced by $E$. canadensis are phenolic compounds (Erhard and Gross, 2006), which Synechococcus may be able to neutralize (Wurster et al., 2003). S. leopoliensis thus may be able to neutralize the little (if any) phenolic compounds produced by subhealthy E. canadensis, but not the full-strength allelochemical production by actively growing E. canadensis. However, further studies are needed to test this hypothesis.

An apparent ineffectiveness in allelochemical production and/or nutrient sequestration by $E$. canadensis allowed S. leopoliensis to take an early advantage of the available nutrients, possibly further weakening $E$. canadensis and inducing nutrient leaching from withering, "leaky" sprigs. Bacteria in nonaxenic flasks may have further increased nutrient availability by transforming sprig-leaked nutrients from organic into inorganic forms (Pehlivanoglu and Sedlak, 2004). Once well established in the flasks, $S$. leopoliensis also may have further reduced $P$ availability for $E$. canadensis by coprecipitating $P$ with calcite (Dittrich et al., 2003). Senescing macrophyte tissue also releases carbon $(C)$ that may be rapidly converted into readily available inorganic forms (Anesio et al., 1999), leading to a concerted increase in nutrient availability for S. leopoliensis while E. canadensis progressively withered. Senescing E. canadensis also may be more susceptible than $C$. demersum to colonization by microdecomposers (Czeczuga et al., 2005), possibly enhancing nutrient leaching from withering $E$. canadensis. Favored by its minute size, high $\mathrm{CO}_{2}$ and $\mathrm{P}$ affinity, and adaptive, combined ability to take up inorganic $\mathrm{C}$ and $\mathrm{N}$ at increasing availability (Ritchie et al., 2001; Tandeau de Marsac et al., 2001), S. leopoliensis may have heavily contributed to the demise of $E$. canadensis in all but the August flasks (Figure 1 ). The dramatic $d_{3}-d_{4}$ recovery by E. canadensis, however, suggests that sprigs were sufficiently healthy or active in August that they were able to successfully counteract $S$. leopoliensis's initial advantage. The mechanism(s) behind such a recovery remain(s) unknown.

Sprig-algae/cyanobacteria interactions in our experimental flasks always led to dominance of either organism type, and coexistence (as both types of organisms coexisting in active growth phase) was never observed despite the short experimental duration (Figure 3). Using larger microcosms ( 120 L), Li et al. (2009) observed that growth, photosynthesis, and cyanobacterial inhibitory capabilities of an Asian species of Ceratophyllum were inversely proportional to cyanobacterial density, with eventual plant biomass loss under the highest experimental cyanobacterial density, supporting our view of a two-way close-range interaction between macrophytes and phytoplankton. Such an "either-or" small-scale pattern resembles the macrophyte-phytoplankton mutual exclusion often observed in larger or natural settings (Hasler and Jones, 1949; Mjelde and Faafeng, 1997). Apparently contradicting results in preliminary trials, with inhibition of target algae by $E$. canadensis but not $C$. demersum (Mjelde and Brettum, unpublished data), and the dramatic divergence in the outcomes of $C$. demersum- vs. E. canadensis-cyanobacteria interactions, further suggests that, as in larger settings (Scheffer, 1998) or in modeled systems (Hulot and Huisman, 2004), the interaction outcome may be determined stochastically or by some initial condition progressively reinforcing and establishing the initial direction, rather than being rigidly "predetermined" a priori. Though to varying extent, many algal and plant species share the ability to quickly adapt to increasing 
nutrient availability (Touchette and Burkholder, 2001; Collos et al., 2005) and/or coprecipitate P with calcite during active photosynthesis (e.g., Brammer, 1979; Hartley et al., 1995), also supporting this hypothesis.

\section{> IN SITU PHYTOPLANKTON SURVEY AND EXTRAPOLATION TO ECOSYSTEM-WIDE FEATURES}

All major chlorophyte taxa and chlorophytes as a group were not influenced by macrophyte presence in the field (Appendix Tables A-V and A-VI). The chlorophyte R. subcapitata was even a codominant in $C$. demersum-dominated Spiradammen, in clear contrast with the growth inhibition observed in $C$. demersum presence in the laboratory (Figure 1), but in agreement with an in situ neutral or mildly enhancing effect on chlorophytes by $\mathrm{C}$. demersum (Jasser, 1995). Though differences were less dramatic, a similar discrepancy between laboratory and field patterns was observed also for $E$. canadensis, suggesting that nutrientand/or allelochemical-(co)mediated sprig effects in close-range macrophyte-chlorophyte interactions do not propagate at medium range (macrophyte stand and vicinity).

Nutrient mediation, and possibly even competition for nutrients, was the primary factor involved in chlorophyte regulation by macrophyte sprigs in the laboratory (Figure 4 and Table II), and estimated nutrient uptake rates by sprigs in flasks (Appendix Table A-IV) also were in the lower end of the typically high range for similar short-term experiments (e.g., Hilt and Lombardo, 2010). However, Lombardo and Cooke (2003) found that net foliar P uptake by postpeak (i.e., midsummer/autumnal) C. demersum and other small-leaved macrophyte species, including Elodea spp., approach zero for exposure periods $\geqslant 10$ weeks, suggesting that strong nutrient effects in short-term small-scale investigations may be an experimental artifact and may not transfer into natural situations - at least not at the magnitude observed in the laboratory. In situ observations of lower-than-expected phytoplankton biomass, but not TP concentration, in richly vegetated natural habitats (Rooney and Kalff, 2003; Lombardo, 2005) similarly support Lombardo and Cooke's (2003) hypothesis that direct competition for water-column nutrients may not contribute to low midsummer phytoplankton biomass in macrophyte-rich shallow waters, though competition may occur during macrophyte early spring growth (van Donk et al., 1993). Small contributions to in situ total nutrient retention by well-established macrophytes was observed also in other aquatic systems (Lehmann et al., 1994; Schulz et al., 2003), further supporting our hypothesis.

The only clear in situ macrophyte effects were closer nutrient-phytoplankton associations (comparison of $p$ values in Table III) coupled to season-long significantly lower total phytoplankton biovolume (Appendix Table A-V) inside than outside the $E$. canadensis stand in Østensjøvatn, suggesting that some nutrient-mediated regulation of phytoplankton biovolume by macrophytes may occur at the medium-scale (macrophyte stand) as well as the small scale (laboratory flasks). Absence of a comparable C. demersum effect in Spiradammen suggests that interspecific differences in plant condition, metabolism, or biomass may have played a role in the observed in situ patterns. For example, while nutrient uptake for the rootless $C$. demersum is exclusively foliar (Denny, 1972), the rooted $E$. canadensis may also function as a nutrient source, translocating sediment nutrients from roots to shoots, thus potentially enriching the water column (Rørslett et al., 1986). Sediment-extracted nutrients are typically stored in plant tissues in healthy, dense E. canadensis stands (Rørslett et al., 1986; D. Berge, NIVA, pers. comm.). However, subhealthy $E$. canadensis was not always able to retain nutrients (Figure 4), and the close, positive nutrient-phytoplankton association inside the E. canadensis stand (Table III) could have simply reflected nutrient-mediated interactions over a wider range of nutrient concentrations (thus leading to a significant correlation) than for $C$. demersum, consistent with the laboratory findings.

Increased sedimentation and/or decreased sediment/algal resuspension in macrophyte stands as tall as $20 \mathrm{~cm}$ (Vermaat et al., 2000) suggest that, though subhealthy and stunted, the $E$. canadensis stand may have been sufficient to act as a physical trap against phytoplankton. Absence of any selective macrophyte action on phytoplankton groups and taxa 
(Appendix Tables A-V and A-VI) supports this hypothesis. Sufficiently tall macrophytes also may minimize water movements within and in close proximity of the stands, creating "microstratifications" in which nutrients may become rapidly depleted, leading to strong, albeit temporary, local competition (Ondok et al., 1984; Jones et al., 1996; Herb and Stefan, 2004), contributing to shape the in situ patterns that we observed (Figure 5 and Table III).

Phytoplankton readily taking advantage of dramatic increases in nutrient availability in eutrophic, E. canadensis-dominated Østensjøvatn (Figure 5) suggests that any close- or medium-range and/or short-term nutrient-mediated regulation of phytoplankton growth by macrophytes may have been overridden by ecosystem-wide changes in trophic state. Such a hypothesis is supported by the observation that in situ phytoplankton responded quickly to the nutrient surge in August (Figure 5), despite E. canadensis's relative "well-being" and close-range effectiveness against all test organisms in the laboratory (Figure 1). Between-lake differences in phytoplankton patterns were generally stronger than within-lake differences, further supporting the hypothesis that lake effects may have overridden any close-range or stand-scale effect of macrophytes. The two lakes shared only one major taxon (Rhodomonas lacustris), but assemblage composition was highly similar inside and outside macrophyte stands in either lake ( $p \geqslant 0.650$ for paired-sample $t$-tests and \%PSC $>50 \%$ ), with most taxa common to both subhabitats (Figure 5). Biovolumes of some major groups were significantly lower $(p \leqslant 0.021$ for paired-sample $t$-tests for cyanobacteria, diatoms and cryptophytes) in Spiradammen, while within-lake differences remained highly qualitative (Appendix Tables A-V and A-VI). The significantly higher total number of phytoplankton taxa in Østensjøvatn ( $p=0.0004$ for the paired-sample $t$-test) similarly may be ascribed to a lake effect, as species richness tends to be proportional to lake area (Jones et al., 2003). Larger betweenthan within-lake differences occurred also for physico-chemical variables such as nutrient concentrations and water transparency (Figure 5; statistical details in Results).

Phytoplankton in C. demersum-dominated Spiradammen did not take advantage of fluctuating nutrient concentrations (e.g., a $\sim 2 x$ increase in TDP in July: Figure 5), resulting in a decoupling of the nutrient-phytoplankton association (Table III). Even more than for the sparse $E$. canadensis stands in Østensjøvatn, inorganic $\mathrm{C}$ may have become depleted in the dense C. demersum stands, leading to a possible strong, local $\mathrm{C}$ limitation of phytoplankton in richly vegetated Spiradammen, at least during daily peaks in macrophyte photosynthesis; however, this hypothesis remains untested. In situ competition between $C$. demersum and phytoplankton for macronutrients other than N, P, or C also was unlikely. For example, similar abundance in Spiradammen and Østensjøvatn of other Si-requiring phytoplankton such as chrysophytes ( $p>0.05$ for between-lake $t$-tests; detailed results not shown), suggest an unlikely involvement of Si in regulating diatom dynamics in Spiradammen. As for diatoms, cyanobacterial abundance in Spiradammen was uncharacteristically low when compared to the in-lake mesotrophic nutrient level, as well as when compared with other $C$. demersumdominated, mesotrophic shallow lakes in southeastern Norway (M. Mjelde, unpublished data). Cyanobacteria typically have high physiological requirements for $\mathrm{P}$ (Wetzel, 2001), and none of the taxa found in Spiradammen is known to fix atmospheric $\mathrm{N}_{2}$, suggesting that nutrients may have regulated cyanobacterial biomass to some extent. However, cyanobacterial biovolume remained too low to be primarily or solely explained by nutrient limitation. Densely growing, canopy-forming macrophytes such as $C$. demersum may effectively shade underlying phytoplankton to the point of halting photosynthesis (Goulder, 1969; Frodge et al., 1990), possibly suppressing phytoplankton locally. However, as Secchi depth was to bottom during most of the growing season (Figure 5), and C. demersum grew to the surface only in part of the lake, light limitation was an unlikely factor in the observed lake-wide low phytoplankton biovolume in Spiradammen. As found elsewhere, (e.g., Hilt, 2006), these patterns suggest a possible involvement of $C$. demersum allelochemicals in determining in situ cyanobacterial patterns.

Besides trophic state, the two study lakes also differed in surface area, shoreline characteristics, and total macrophyte coverage. The observed between-lake differences may have been driven by more than one factor, possibly acting simultaneously, with varying magnitude, and 
interacting in nonlinear ways. For example, the ability of macrophyte stands to trap and retain suspended particles (Ackerman and Okubo, 1993; Vermaat et al., 2000) may have been much greater in Spiradammen, whose sediment surface was almost entirely covered by macrophytes. In fact, coverage rather than biovolume may be more important in determining the "filtering" capability of macrophyte stands, as even short plant beds can be effective particle traps (Vermaat et al., 2000). Between-lake differences in macrophyte-based particle-trapping ability may have been exacerbated by different lake surface areas, as larger lakes (in this case, Østensjøvatn) tend to be more prone to wind-induced water/nutrient recirculation and sustained phytoplankton biovolume (Jeppesen et al., 1990; Guildford et al., 1994). In their extensive review, Gasith and Hoyer (1997) also argue that the lake-wide limnological and metabolic effects of submerged macrophytes decrease with increasing lake size faster than their importance in providing a structural habitat, emphasizing the importance of lake size in determining its metabolism. Differences in shoreline characteristics also may have played a role, with much of Spiradammen being protected from wind action by tall riparian trees, while most of the Østensjøvatn shoreline at the outlet (i.e., sampling) area was relatively open. Though they remain largely untested, these hypotheses are consistent with the general observation that the probability of dominance by submerged macrophytes decreases with increasing lake surface area (Duarte et al., 1986; Gasith and Hoyer, 1997; van Geest et al., 2003).

\section{CONCLUSIONS}

Though the effects of sensu latu competition for nutrients and allelopathy could not be satisfactorily separated in laboratory experiments, our results suggest that 1 . close-range, shortterm macrophyte-phytoplankton interactions lead to dominance by either organism type, mirroring the longer-term, larger-scale mutual exclusion typically observed in natural conditions; 2. regardless of the mechanisms involved, close-range, short-term interactions are driven by macrophytes; 3. outcomes of close-range interactions may (co)depend on some initial condition (e.g., macrophyte health) rather than being rigidly determined a priori; 4. sensu latu competition for nutrients is likely the primary factor involved in chlorophyte and diatom closerange regulation by $C$. demersum and $E$. canadensis under laboratory conditions; 5 . allelochemicals are likely involved in close-range cyanobacterial inhibition by $C$. demersum; 6 . apparently subhealthy $E$. canadensis is ineffective against otherwise susceptible cyanobacteria; 7. regardless of the mechanisms involved, macrophytes exert close-range control over phytoplankton only when actively growing; 8 . competition for nutrients and/or allelopathy do(es) not seem to be primary factor(s) involved in in situ macrophyte-phytoplankton patterns; and 9. in situ macrophyte-phytoplankton patterns may be strongly influenced by ecosystem-wide factors such as trophic state, wind exposure, extent of total submerged vegetation coverage and related lake-wide sedimentation capabilities.

\section{ACKNOWLEDGEMENTS}

We greatly appreciate the help of Ms. Randi Romstad with cell counts and fluorescence determinations for laboratory experiments, and the NIVA analytical lab (NS-EN ISO/IEC 17025 accredited) for nutrient determinations. We thank Prof. Dr. Bazyli Czeczuga (Medical University of Białystok, PL) for delucidating some aspects of macrophyte susceptibility to microdecomposers. Dr. F. Paolo Miccoli (University of L'Aquila) reviewed an earlier version of the manuscript. Our manuscript was also greatly improved by the editors, reviewers, and publishing staff at KMAE. This project was supported by NIVA funds awarded to PL (project \# O-40027).

\section{REFERENCES}

Ackerman J.D. and Okubo A., 1993. Reduced mixing in a marine macrophyte canopy. Funct. Ecol., 7 , 305-309. 
Anesio A.M., Tranvik L.J. and Granéli W., 1999. Production of inorganic carbon from aquatic macrophytes by solar radiation. Ecology, 80, 1852-1859.

Blindow I., Hargeby A. and Andersson G., 2002. Seasonal changes of mechanisms maintaining clear water in a shallow lake with abundant Chara vegetation. Aquat. Bot., 72, 315-334.

Bouterfas R., Belkoura M. and Dauta A., 2002. Light and temperature effects on the growth rate of three freshwater algae isolated from a eutrophic lake. Hydrobiologia, 489, 207-217.

Brammer E.S., 1979: Exclusion of phytoplankton in the proximity of dominant water-soldier (Stratiotes aloides). Freshw. Biol., 9, 233-249.

Collos Y., Vaquer A. and Souchu P., 2005. Acclimation of nitrate uptake by phytoplankton to high substrate levels. J. Phycol., 41, 466-478.

Connell J.H., 1980. Diversity and the coevolution of competitors, or the ghost of competition past. Oikos, 35, 131-138.

Connell J.H., 1983. On the prevalence and relative importance of interspecific competition: evidence from field experiments. Am. Nat., 122, 661-696.

Craine J.M., Fargione J. and Sugita S., 2005. Supply pre-emption, not concentration reduction, is the mechanism of competition for nutrients. New Phytol., 166, 933-940.

Czeczuga B., Mazalska B., Godlewska A. and Muszyńska E., 2005. Aquatic fungi growing on dead fragments of submerged plants. Limnologica, 35, 283-297.

Denny P., 1972. Sites of nutrient absorption in aquatic macrophytes. J. Ecol., 60, 819-829.

Dittrich M., Müller B., Mavrocordatos D. and Wehrli B., 2003. Induced calcite precipitation by cyanobacterium Synechococcus. Acta Hydrochim. Hydrobiol., 31, 162-169.

Duarte C.M., Kalff J. and Peters R.H., 1986. Patterns in biomass and cover of aquatic macrophytes in lakes. Can. J. Fish. Aquat. Sci., 43, 1900-1908.

Erhard D. and Gross E.M., 2006. Allelopathic activity of Elodea canadensis and Elodea nuttallii against epiphytes and phytoplankton. Aquat. Bot., 85, 203-211.

Faafeng B.A. and Hessen D.O., 1993. Nitrogen and phosphorus concentrations and N:P ratios in Norwegian lakes: perspectives on nutrient limitation. Verh. Int. Verein. Limnol., 25, 465-469.

Frodge J.D., Thomas G.L. and Pauley G.B., 1990. Effects of canopy formation by floating and submergent aquatic macrophytes on the water quality of two shallow Pacific Northwest lakes. Aquat. Bot., 38, 231-248.

Gabestad H., 2001. Restaurering av Østensjøvannet. Prosjekt "Renere Østensjøvann", Sluttrapport med forslag til tiltak. Oslo Kommune, Vann-og Avløpsetaten. Oslo, [in Norwegian] N.

Gasith A. and Hoyer M.V., 1997. Structuring role of macrophytes in lakes: changing influence along lake size and depth gradients. In: Jeppesen E., Søndergaard Ma., Søndergaard Mo. and Christoffersen K. (eds.), The Structuring Role of Submerged Macrophytes in Lakes. Springer, New York, NY, 381-392.

Geider R.J., Osborne B.A. and Raven J.A., 1986. Growth, photosynthesis and maintenance metabolic costs in the diatom Phaeodactylum tricornutum at very low light levels. J. Phycol., 22, 39-48.

Gligora M., Plenković-Moraj A., Kralj K., Grigorszky I. and Peroš-Pucar D., 2007. The relationship between phytoplankton species dominance and environmental variables in a shallow lake (Lake Vrana, Croatia). Hydrobiologia, 584, 337-346.

Goldberg D.E. and Scheiner S.M., 2001. ANOVA and ANCOVA: field competition experiments. In: Scheiner S.M. and Gurevitch J. (eds.), Design and Analysis of Ecological Experiments, 2nd edn. Oxford Univ. Press, New York, NY, 77-98.

Goulder R., 1969. Interactions between the rates of production of a freshwater macrophyte and phytoplankton in a pond. Oikos, 20, 300-309.

Goulder R. and Boatman D.J., 1971. Evidence that nitrogen supply influences the distribution of a freshwater macrophyte, Ceratophyllum demersum. J. Ecol., 59, 783-791.

Gross E.M., 1995. Allelopathische Interaktionen zwischen Makrophyten und Epiphyten: Die Rolle hydrolysierbarer Polyphenole aus Myriophyllum spicatum. PhD Dissertation, University of Kiel, Kiel, D.

Gross E.M., 2000. Seasonal and spatial dynamics of allelochemicals in the submersed macrophyte Myriophyllum spicatum L. Verh. Int. Verein. Limnol., 27, 2116-2119. 
Gross E.M., 2003. Differential response of tellimagrandin II and total bioactive hydrolysable tannins in an aquatic angiosperm to changes in light and nitrogen. Oikos, 103, 497-504.

Gross E.M., Meyer H. and Schilling G., 1996. Release and ecological impact of algicidal hydrolyzable polyphenols in Myriophyllum spicatum. Phytochemistry, 41, 133-138.

Gross E.M., Erhard D. and Iványi E., 2003. Allelopathic activity of Ceratophyllum demersum L. and Najas marina ssp. intermedia (Wolfgang) Casper. Hydrobiologia, 506-509, 583-589.

Gross E.M., Hilt S., Lombardo P. and Mulderij G., 2007. Searching for allelopathic effects of submerged macrophytes on phytoplankton - state of the art and open questions. Hydrobiologia, 584, 77-88.

Guildford S.J., Hendzel L.L., Kling H.J., Fee E.J., Robinson G.G.C., Hecky R.E. and Kasian S.E.M., 1994. Effects of lake size on phytoplankton nutrient status. Can. J. Fish. Aquat. Sci., 51, 2769-2783.

Guiry M.D. and Guiry G.M., 2012. AlgaeBase - World-wide electronic publication, National University of Ireland, Galway, IE. http://www.algaebase.org; last accessed 3 July 2013.

Hartley A.M., House W.A., Callow M.E. and Leadbeater S.C., 1995. The role of a green alga in the precipitation of calcite and the coprecipitation of phosphate in freshwater. Int. Rev. gesamt. Hydrobiol., $80,385-401$.

Hasler A.D. and Jones E., 1949. Demonstration of the antagonistic action of large aquatic plants on algae and rotifers. Ecology, 30, 359-364.

Herb W.R. and Stefan H.G., 2004. Temperature stratification and mixing dynamics in a shallow lake with submersed macrophytes. Lake Reserv. Manage., 20, 296-308.

Hilt S., 2006. Allelopathic inhibition of epiphytes by submerged macrophytes. Aquat. Bot., 86, $252-256$.

Hilt S. and Gross E.M., 2008. Can allelopathically active submerged macrophytes stabilise clear-water states in shallow lakes? Basic Appl. Ecol., 9, 422-432.

Hilt S. and Lombardo P., 2010. Effects of macrophytes on phytoplankton: nutrient uptake versus allelopathy. Verh. Int. Verein. Limnol., 30, 1317-1320.

Hilt S., Ghobrial M.G.N. and Gross E.M., 2006. In situ allelopathic potential of Myriophyllum verticillatum (Haloragaceae) against selected phytoplankton species. J. Phycol., 42, 1189-1198.

Hulot F.D. and Huisman J., 2004. Allelopathic interactions between phytoplankton species: the roles of heterotrophic bacteria and mixing intensity. Limnol. Oceanogr., 49, 1424-1434.

ISO, 2004. Water quality - Fresh water algal growth inhibition test with unicellular green algae. International Organization for Standardization, Geneva, $\mathrm{CH}$.

Jasser I., 1995. The influence of macrophytes on a phytoplankton community in experimental conditions. Hydrobiologia, 306, 21-32.

Jeppesen E., Jensen J.P., Kristensen P., Søndergaard M., Mortensen E., Sortkjær O. and Olrik K., 1990. Fish manipulation as a lake restoration tool in shallow, eutrophic, temperate lakes. 2: Threshold levels, long-term stability and conclusions. Hydrobiologia, 200/201, 219-227.

Jones J.I., Hardwick K. and Eaton J.W., 1996. Diurnal carbon restrictions on the photosynthesis of dense stands of Elodea nuttallii (Planch.) St. John. Hydrobiologia, 340, 11-16.

Jones J.I., Li W. and Maberly S.C., 2003. Area, altitude and aquatic plant diversity. Ecography, 26, 411-420.

Jørgensen E.G., 1969. The adaptation of plankton algae. IV. Light adaptation in different algal species. Physiol. Plant., 22, 1307-1315.

Körner S. and Nicklisch A., 2002. Allelopathic growth inhibition of selected phytoplankton species by submerged macrophytes. J. Phycol., 38, 862-871.

Lehmann A., Jacquet J.-M. and Lachavanne J.-B., 1994. Contribution of GIS to submerged macrophyte biomass estimation and community structure modeling, Lake Geneva, Switzerland. Aquat. Bot., 47, 99-117.

Li D., Li G., Chen W. and Liu Y., 2009. Interactions between a cyanobacterial bloom (Microcystis) and the submerged aquatic plant Ceratophyllum oryzetorum Kom. Chin. J. Ocean. Limnol., 27, 38-42.

Lombardo P., 2005. Applicability of littoral food-web biomanipulation for lake management purposes: snails, macrophytes, and water transparency in northeast Ohio shallow lakes. Lake Reserv. Manage., 21, 186-202.

Lombardo P. and Cooke G.D., 2003. Ceratophyllum demersum - phosphorus interactions in nutrient enriched aquaria. Hydrobiologia, 497, 79-90. 
Lürling M., van Geest G. and Scheffer M., 2006. Importance of nutrient competition and allelopathic effects in suppression of the green alga Scenedesmus obliquus by the macrophytes Chara, Elodea and Myriophyllum. Hydrobiologia, 556, 209-220.

Mjelde M. and Faafeng B.A., 1997. Ceratophyllum demersum hampers phytoplankton development in some small Norwegian lakes over a wide range of phosphorus level and geographical latitude. Freshw. Biol. , 37, 355-365.

Nakai S., Inoue Y., Hosomi M. and Murakami A., 1999. Growth inhibition of blue-green algae by allelopathic effects of macrophytes. Water Sci. Tech., 39(8), 47-53.

OECD, 2011. OECD Guidelines for the Testing of Chemicals, Section 2 - Test No. 201: Freshwater Algae and Cyanobacteria, Growth Inhibition Tests. Organization for Economic Cooperation and Development, Paris, F. DOI : 10.1787/20745761. Available at http://www.oecd-ilibrary.org/content/ book/9789264069923-en; last accessed 4 July 2013.

Olrik K., Blomqvist P., Cronberg G., Brettum P. and Eloranta P., 1998. Methods for quantitative assessment of phytoplankton in freshwaters, part 1. Naturvårdsverkets report No. 4860.

Ondok J.P., Pokorný J. and Květ J., 1984. Model of diurnal changes in oxygen, carbon dioxide and bicarbonate concentrations in a stand of Elodea canadensis Michx. Aquat. Bot., 19, 293-305.

Ozimek T. and Balcerzak D., 1976. Macrophytes. In: Pieczyńska E. (ed.), Selected Problems of Lake Littoral Ecology. Wydawnictwa Uniwersytetu Warszawskiego, Warszawa, PL, 33-53.

Pehlivanoglu E. and Sedlak D.L., 2004. Bioavailability of wastewater-derived organic nitrogen to the alga Selenastrum capricornutum. Water Res., 38, 3189-3196.

Pelton D.K., Levine S.N. and Braner M., 1998. Measurement of phosphorus uptake by macrophytes and epiphytes from the LaPlatte River (VT) using ${ }^{32} \mathrm{P}$ in stream microcosms. Freshw. Biol., 39, 285-299.

Pip E. and Philipp K., 1990. Seasonal changes in the chemical composition of Ceratophyllum demersum L. in a small pond. Int. Rev. gesamt. Hydrobiol., 75, 71-78.

Quinn G.P. \& Keough M.J., 2002. Experimental Design and Data Analysis for Biologists. Cambridge Univ. Press, Cambridge, UK.

Ritchie R.J., Trautman D.A. and Larkum A.W.D., 2001. Phosphate limited cultures of the cyanobacterium Synechococcus are capable of very rapid, opportunistic uptake of phosphate. New Phytol., 152, 189-201.

Rooney N. and Kalff J., 2003. Submerged macrophyte-bed effects on water-column phosphorus, chlorophyll a, and bacterial productivity. Ecosystems, 6, 797-807.

Rørslett B., Berge D. and Johansen S.W., 1986. Lake enrichment by submersed macrophytes: a Norwegian whole-lake experience with Elodea canadensis. Aquat. Bot., 26, 325-340.

Sand-Jensen K. and Madsen T.V., 1991. Minimum light requirements of submerged freshwater macrophytes in laboratory growth experiments. J. Ecol., 79, 749-764.

Scheffer M., 1998. Ecology of Shallow Lakes, reprinted with corrections 2004, Kluwer Academic Publ., Dordrecht, NL.

Schulz M., Rinke K. and Köhler J., 2003. A combined approach of photogrammetrical methods and field studies to determine nutrient retention by submersed macrophytes in running waters. Aquat. Bot., 76, 17-29.

Takeda F., Shioiri M., Nomura M., Nakano K. and Nishimura O., 2008. Comparison of a novel bioassay method and previous methods for ecological impact assessment using microalgae. Environm. Engineer. Res., 45, 163-168. [In Japanese]

Takeda F., Nakano K., Nishimura O., Shimada Y., Fukuro S., Tanaka H., Hayashi N. and Inamori Y., 2011. Allelopathic potential of Potamogeton pusillus community against Microcystis aeruginosa. J. Water Environm. Tech., 9, 21-28.

Tandeau de Marsac N., Lee H.M., Hisbergues M., Castets A.M. and Bédu S., 2001. Control of nitrogen and carbon metabolism in cyanobacteria. J. Appl. Phycol., 13, 287-292.

Thiébaut G., 2005. Does competition for phosphate supply explain the invasion pattern of Elodea species? Water Res., 39, 3385-3393.

Touchette B.W. and Burkholder J.M., 2001. Nitrate reductase activity in a submersed marine angiosperm: controlling influences of environmental and physiological factors. Plant Physiol. Biochem., 39, 583-593.

van Donk E., Gulati R.D., ledema A. and Meulemans J.T., 1993. Macrophyte-related shifts in the nitrogen and phosphorus contents of the different tophic levels in a biomanipulated shallow lake. Hydrobiologia, 251, 19-26. 
van Geest G.J.F., Roozen C.J.M., Coops H., Roijackers R.M.M., Buijse A.D., Peeters E.T.H.M. and Scheffer M., 2003. Vegetation abundance in lowland flood plain lakes determined by surface area, age and connectivity. Freshw. Biol., 48, 440-454.

Vermaat J.E., Santamaría L. and Roos P.J., 2000. Water flow across and sediment trapping in submerged macrophyte beds of contrasting growth form. Arch. Hydrobiol., 148, 549-562.

Wetzel R.G., 2001. Limnology - Lake and River Ecosystems, 3rd ed., Academic Press, San Diego, CA.

Whittaker R.H., 1952. A study of summer foliage insect communities in the Great Smoky Mountains. Ecol. Monogr., 22, 1-44.

Wium-Andersen S., 1987. Allelopathy among aquatic plants. Arch. Hydrobiol. Beih. Ergeb. Limnol., 27, 167-172.

Wurster M., Mundt S., Hammer E., Schauer F. and Lindequist U., 2003. Extracellular degradation of phenol by the cyanobacterium Synechococcus PCC 7002. J. Appl. Phycol., 15, 171-176.

Zar J.H., 2009. Biostatistical Analysis, 5th edn. Pearson / Prentice Hall, Upper Saddle River, NJ. 


\section{APPENDIX}

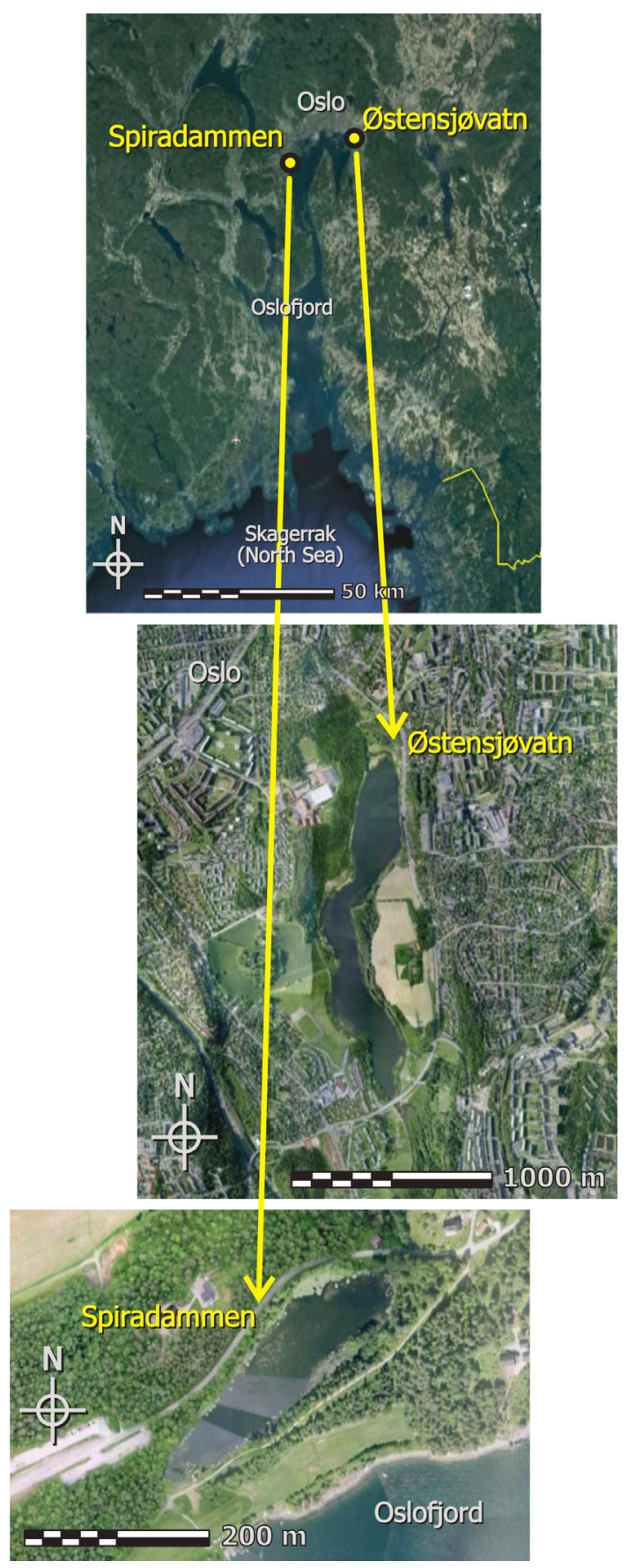

\section{Figure A-1}

Location of C. demersum-dominated Spiradammen and E. canadensis-dominated Østensjøvatn in southeastern Norway. Spiradammen (59 $\left.50^{\prime} 9^{\prime \prime} N, 10^{\circ} 29^{\prime} 52^{\prime \prime} E\right)$ is located near the city of Asker and Østensjøvatn (59 $\left.53^{\prime} 40^{\prime \prime} \mathrm{N}, 10^{\circ} 49^{\prime} 49^{\prime \prime} \mathrm{E}\right)$ is located in the southeastern suburbs of Oslo. In situ data collection in larger Østansjøvatn was restricted to the northern area to have comparable sampling surface areas in the two lakes. Maps elaborated from Google Earth images (C)2013 Google \& Cnes/Spot Images). 


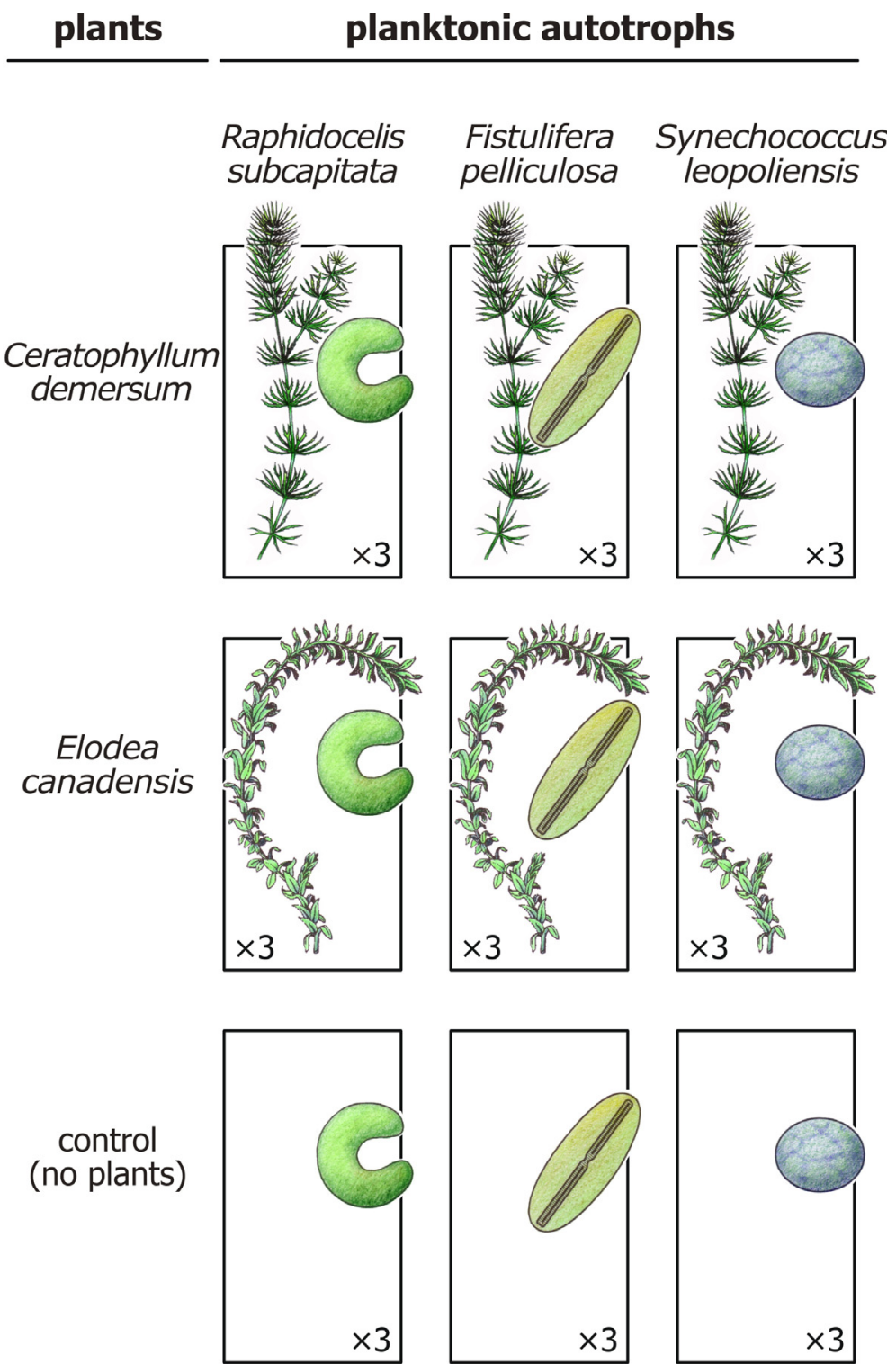

Figure A-2

Experimental design for each of four trials of the laboratory experiment using whole $C$. demersum or $E$. canadensis sprigs. Each condition was carried out in triplicate. Material is not drawn to scale. 
Table A-I

Complete results for the repeated-measures-ANOVAs and a posteriori Tukey HSD tests for the short-term flask experiments described in Figure 1. Statistical tests were performed on square-roottransformed data. Degrees of freedom were 2,6, 4,24, and 8,24 for plant, time, and plant $\times$ time interaction factors, respectively, for repeated-measures-ANOVAs, except in September, when $d f=3,18$ and 6,18 for time and interaction. For one-way ANOVAs testing differences in plant condition within each experimental day, ctrl = control (no plants), C.dem = C. demersum, and E.can $=$ E. canadensis; $d f=2,6$ for each test. ANOVAs were considered significant for $p \leqslant 0.05$. Day-specific ANOVAs and HSD tests were not performed ("-") when repeated-measures $p_{\text {plant }}>0.05$. Day-zero one-way ANOVAs (always not significant: $F \approx 0, p \approx 1$ ) and associated HSD are not reported. For HSD tests, different letters identify significantly different average values at $p \leqslant 0.05$, with "a" = lowest and with increasing average values progressively identified alphabetically.

\begin{tabular}{|c|c|c|c|c|c|c|c|c|c|c|}
\hline & \multicolumn{10}{|c|}{ Raphidocelis subcapitata } \\
\hline & \multicolumn{3}{|c|}{$\begin{array}{c}\text { Repeated-measures } \\
\text { ANOVA }\end{array}$} & \multicolumn{3}{|c|}{$\begin{array}{c}\text { Day-specific one-way } \\
\text { ANOVAs }\end{array}$} & \multicolumn{4}{|c|}{$\begin{array}{l}\text { Day-specific } \\
\text { Tukey HSD tests }\end{array}$} \\
\hline & & $F$ & $p$ & & $F$ & $p$ & & ctrl & C.dem & E.can \\
\hline \multirow{5}{*}{ Jun } & plant & 13.079 & 0.006 & $d_{1}$ & 7.675 & 0.022 & $d_{1}$ & $a$ & $\mathrm{~b}$ & $a b$ \\
\hline & time & 229.753 & $<0.0001$ & $d_{2}$ & 13.209 & 0.006 & $d_{2}$ & a & b & b \\
\hline & plant $\times$ time & 15.312 & $<0.0001$ & $d_{3}$ & 9.964 & 0.012 & $d_{3}$ & $a b$ & a & b \\
\hline & & & & $\mathrm{d}_{4}$ & 16.110 & 0.004 & $d_{4}$ & b & a & b \\
\hline & & $F$ & $p$ & & $F$ & $p$ & & ctrl & C.dem & E.can \\
\hline \multirow{5}{*}{ Jul } & plant & 0.179 & 0.840 & $d_{1}$ & - & - & $d_{1}$ & - & - & - \\
\hline & time & 295.736 & $<0.0001$ & $d_{2}$ & - & - & $d_{2}$ & - & - & - \\
\hline & plant $\times$ time & 4.765 & 0.001 & $d_{3}$ & - & - & $d_{3}$ & - & - & - \\
\hline & & & & $d_{4}$ & - & - & $d_{4}$ & - & - & - \\
\hline & & $F$ & $p$ & & $F$ & $p$ & & ctrl & C.dem & E.can \\
\hline \multirow{5}{*}{ Aug } & plant & 9.147 & 0.015 & $d_{1}$ & 25.924 & 0.001 & $d_{1}$ & $\bar{a}$ & $a$ & $\mathrm{~b}$ \\
\hline & time & 175.369 & $<0.0001$ & $d_{2}$ & 11.970 & 0.008 & $d_{2}$ & a & a & b \\
\hline & plant $\times$ time & 18.789 & $<0.0001$ & $d_{3}$ & 7.719 & 0.022 & $d_{3}$ & $b$ & $a b$ & a \\
\hline & & & & $\mathrm{d}_{4}$ & 17.553 & 0.003 & $\mathrm{~d}_{4}$ & $b$ & a & a \\
\hline & & $F$ & $p$ & & $F$ & $p$ & & ctrl & C.dem & E.can \\
\hline \multirow{4}{*}{ Sep } & plant & 4.596 & 0.062 & $\mathrm{~d}_{1}$ & - & - & $d_{1}$ & - & - & - \\
\hline & time & 866.684 & $<0.0001$ & $\mathrm{~d}_{2}$ & - & - & $d_{2}$ & - & - & - \\
\hline & plant $\times$ time & 4.560 & 0.003 & $d_{3}$ & - & - & $d_{3}$ & - & - & - \\
\hline & & & & $\mathrm{d}_{4}$ & - & - & $\mathrm{d}_{4}$ & - & - & - \\
\hline
\end{tabular}


Table A-I

Continued.

\begin{tabular}{|c|c|c|c|c|c|c|c|c|c|c|}
\hline \multicolumn{11}{|c|}{ Fistulifera pelliculosa } \\
\hline & \multicolumn{3}{|c|}{ Repeated-measures ANOVA } & \multicolumn{3}{|c|}{ Day-specific one-way ANOVAs } & \multicolumn{4}{|c|}{ Day-specific Tukey HSD tests } \\
\hline & & $F$ & $p$ & & $F$ & $p$ & & ctrl & C.dem & E.can \\
\hline \multirow[t]{2}{*}{ Jun } & $\begin{array}{c}\text { plant } \\
\text { time } \\
\text { plant } \times \text { time }\end{array}$ & $\begin{array}{c}449.922 \\
396.487 \\
63.479\end{array}$ & $\begin{array}{l}<0.0001 \\
<0.0001 \\
<0.0001\end{array}$ & $\begin{array}{l}d_{1} \\
d_{2} \\
d_{3} \\
d_{4}\end{array}$ & $\begin{array}{c}9.129 \\
123.506 \\
97.334 \\
192.546\end{array}$ & $\begin{array}{c}0.015 \\
<0.0001 \\
<0.0001 \\
<0.0001\end{array}$ & $\begin{array}{l}d_{1} \\
d_{2} \\
d_{3} \\
d_{4}\end{array}$ & $\begin{array}{l}b \\
b \\
b \\
c\end{array}$ & $\begin{array}{l}a \\
a \\
a \\
a\end{array}$ & $\begin{array}{l}b \\
b \\
b \\
b\end{array}$ \\
\hline & & $F$ & $p$ & & $F$ & $p$ & & ctrl & C.dem & E.can \\
\hline \multirow[t]{2}{*}{ Jul } & $\begin{array}{c}\text { plant } \\
\text { time } \\
\text { plant } \times \text { time }\end{array}$ & $\begin{array}{c}4.892 \\
302.909 \\
4.573\end{array}$ & $\begin{array}{c}0.055 \\
<0.0001 \\
0.001\end{array}$ & $\begin{array}{l}d_{1} \\
d_{2} \\
d_{3} \\
d_{4}\end{array}$ & $\begin{array}{l}- \\
- \\
- \\
-\end{array}$ & $\begin{array}{l}- \\
- \\
- \\
-\end{array}$ & $\begin{array}{l}d_{1} \\
d_{2} \\
d_{3} \\
d_{4}\end{array}$ & $\begin{array}{l}- \\
- \\
- \\
-\end{array}$ & $\begin{array}{l}- \\
- \\
- \\
-\end{array}$ & $\begin{array}{l}- \\
- \\
- \\
-\end{array}$ \\
\hline & & $F$ & $p$ & & $F$ & $p$ & & ctrl & C.dem & E.can \\
\hline \multirow[t]{2}{*}{ Aug } & $\begin{array}{c}\text { plant } \\
\text { time } \\
\text { plant } \times \text { time }\end{array}$ & $\begin{array}{l}62.618 \\
86.298 \\
17.522\end{array}$ & $\begin{array}{l}<0.0001 \\
<0.0001 \\
<0.0001\end{array}$ & $\begin{array}{l}d_{1} \\
d_{2} \\
d_{3} \\
d_{4}\end{array}$ & $\begin{array}{c}2.259 \\
26.587 \\
128.592 \\
15.820\end{array}$ & $\begin{array}{c}0.186 \\
0.001 \\
<0.0001 \\
0.004\end{array}$ & $\begin{array}{l}d_{1} \\
d_{2} \\
d_{3} \\
d_{4}\end{array}$ & $\begin{array}{l}- \\
b \\
c \\
b\end{array}$ & $\begin{array}{l}- \\
b \\
b \\
a\end{array}$ & $\begin{array}{l}- \\
a \\
a \\
a\end{array}$ \\
\hline & & $F$ & $p$ & & $F$ & $p$ & & ctrl & C.dem & E.can \\
\hline Sep & $\begin{array}{c}\text { plant } \\
\text { time } \\
\text { plant } \times \text { time }\end{array}$ & \begin{tabular}{|c|}
4.063 \\
383.794 \\
2.790
\end{tabular} & $\begin{array}{c}0.077 \\
<0.0001 \\
0.033\end{array}$ & $\begin{array}{l}d_{1} \\
d_{2} \\
d_{3} \\
d_{4}\end{array}$ & $\begin{array}{l}- \\
- \\
- \\
-\end{array}$ & $\begin{array}{l}- \\
- \\
- \\
-\end{array}$ & $\begin{array}{l}d_{1} \\
d_{2} \\
d_{3} \\
d_{4}\end{array}$ & $\begin{array}{l}- \\
- \\
- \\
-\end{array}$ & $\begin{array}{l}- \\
- \\
- \\
-\end{array}$ & $\begin{array}{l}- \\
- \\
- \\
-\end{array}$ \\
\hline \multicolumn{11}{|c|}{ Synechococcus leopoliensis } \\
\hline & \multicolumn{3}{|c|}{ Repeated-measures ANOVA } & \multicolumn{3}{|c|}{ Day-specific one-way ANOVAs } & \multicolumn{4}{|c|}{ Day-specific Tukey HSD tests } \\
\hline & & $F$ & $p$ & & $F$ & $p$ & & ctrl & C.dem & E.can \\
\hline Jun & $\begin{array}{c}\text { plant } \\
\text { time } \\
\text { plant } \times \text { time }\end{array}$ & $\begin{array}{c}18.667 \\
11.363 \\
7.248\end{array}$ & $\begin{array}{c}0.003 \\
<0.0001 \\
<0.0001\end{array}$ & $\begin{array}{l}d_{1} \\
d_{2} \\
d_{3} \\
d_{4}\end{array}$ & $\begin{array}{c}22.619 \\
8.869 \\
81.925 \\
6.992\end{array}$ & $\begin{array}{c}0.002 \\
0.016 \\
<0.0001 \\
0.027\end{array}$ & $\begin{array}{l}d_{1} \\
d_{2} \\
d_{3} \\
d_{4}\end{array}$ & $\begin{array}{l}\mathrm{b} \\
\mathrm{a} \\
\mathrm{a} \\
\mathrm{a}\end{array}$ & $\begin{array}{l}a \\
a \\
a \\
a\end{array}$ & $\begin{array}{l}a \\
b \\
b \\
b\end{array}$ \\
\hline & & $F$ & $p$ & & $F$ & $p$ & & ctrl & C.dem & E.can \\
\hline Jul & $\begin{array}{c}\text { plant } \\
\text { time } \\
\text { plant } \times \text { time }\end{array}$ & $\begin{array}{l}33.784 \\
57.428 \\
16.199\end{array}$ & $\begin{array}{c}0.001 \\
<0.0001 \\
<0.0001\end{array}$ & $\begin{array}{l}d_{1} \\
d_{2} \\
d_{3} \\
d_{4}\end{array}$ & $\begin{array}{l}46.766 \\
76.498 \\
20.229 \\
12.666\end{array}$ & $\begin{array}{c}0.0002 \\
<0.0001 \\
0.002 \\
0.007\end{array}$ & $\begin{array}{l}d_{1} \\
d_{2} \\
d_{3} \\
d_{4}\end{array}$ & $\begin{array}{l}a \\
a \\
a \\
b\end{array}$ & $\begin{array}{l}\mathrm{b} \\
\mathrm{a} \\
\mathrm{a} \\
\mathrm{a}\end{array}$ & $\begin{array}{l}c \\
b \\
b \\
b\end{array}$ \\
\hline & & $F$ & $p$ & & $F$ & $p$ & & ctrl & C.dem & E.can \\
\hline Aug & $\begin{array}{c}\text { plant } \\
\text { time } \\
\text { plant } \times \text { time }\end{array}$ & $\begin{array}{c}20.931 \\
9.011 \\
7.939\end{array}$ & $\begin{array}{c}0.002 \\
<0.0001 \\
<0.0001\end{array}$ & $\begin{array}{l}d_{1} \\
d_{2} \\
d_{3} \\
d_{4}\end{array}$ & $\begin{array}{c}7.226 \\
7.646 \\
11.856 \\
47.669\end{array}$ & $\begin{array}{c}0.025 \\
0.022 \\
0.008 \\
0.0002\end{array}$ & $\begin{array}{l}d_{1} \\
d_{2} \\
d_{3} \\
d_{4}\end{array}$ & $\begin{array}{c}a \\
a b \\
b \\
b\end{array}$ & $\begin{array}{c}a b \\
a \\
a \\
a\end{array}$ & $\begin{array}{l}b \\
b \\
b \\
a\end{array}$ \\
\hline & & $F$ & $p$ & & $F$ & $p$ & & ctrl & C.dem & E.can \\
\hline Sep & $\begin{array}{c}\text { plant } \\
\text { time } \\
\text { plant } \times \text { time }\end{array}$ & $\begin{array}{c}40.682 \\
79.566 \\
8.800\end{array}$ & $\begin{array}{c}0.0003 \\
<0.0001 \\
<0.0001\end{array}$ & $\begin{array}{l}d_{1} \\
d_{2} \\
d_{3} \\
d_{4}\end{array}$ & $\begin{array}{c}\mathrm{np} \\
24.533 \\
19.195 \\
18.888\end{array}$ & $\begin{array}{c}\mathrm{np} \\
0.001 \\
0.002 \\
0.003\end{array}$ & $\begin{array}{l}d_{1} \\
d_{2} \\
d_{3} \\
d_{4}\end{array}$ & $\begin{array}{c}\mathrm{np} \\
\mathrm{a} \\
\mathrm{a} \\
\mathrm{a}\end{array}$ & $\begin{array}{c}\mathrm{np} \\
\mathrm{a} \\
\mathrm{a} \\
\mathrm{a}\end{array}$ & $\begin{array}{c}\mathrm{np} \\
\mathrm{b} \\
\mathrm{b} \\
\mathrm{b}\end{array}$ \\
\hline
\end{tabular}

np: not performed (fluorescence-based density not determined because of instrumentation failure). 


\section{Table A-II}

Paired-sample two-tailed $t$-tests comparing macrophyte sprig net growth in the presence of each tested phytoplankton taxon, reported visually in Figure 2. Tests were performed on arcsine-transformed data, with final sprig biomass expressed as percent departure from initial condition (initial biomass $=100 \%$, biomass accrual $>100 \%$ and biomass loss $<100 \%) ; n=4$ and $d f=3$ for each comparison. Negative $t$ values represent biomass loss from initial condition. Significant $t$ values are highlighted with $\bigcirc(p \leqslant 0.05)$, $\bigcirc \bigcirc(p \leqslant 0.01)$, and $\bigcirc \bigcirc(p \leqslant 0.0001)$.

\begin{tabular}{|c|c|c|c|}
\hline \multicolumn{4}{|c|}{ Ceratophyllum demersum } \\
\hline & R. subcapitata & F. pelliculosa & S. leopoliensis \\
\hline Jun & $\begin{array}{c}t=6.264 \\
p=0.025^{\circ}\end{array}$ & $\begin{array}{c}t=25.324 \\
p=0.002 \bigcirc \bigcirc\end{array}$ & $\begin{array}{c}t=5.534 \\
p=0.031^{\circ}\end{array}$ \\
\hline Jul & $\begin{array}{l}t=-0.176 \\
p=0.877\end{array}$ & $\begin{array}{c}t=6.677 \\
p=0.022\end{array}$ & $\begin{array}{l}t=0.532 \\
p=0.648\end{array}$ \\
\hline Aug & $\begin{array}{l}t=2.078 \\
p=0.173\end{array}$ & $\begin{array}{l}t=1.174 \\
p=0.361\end{array}$ & $\begin{array}{l}t=2.786 \\
p=0.108\end{array}$ \\
\hline Sep & $\begin{array}{l}t=-5.056 \\
p=0.037\end{array}$ & $\begin{array}{c}t=-0.713 \\
p=0.550\end{array}$ & $\begin{array}{l}t=-5.237 \\
p=0.035^{\circ}\end{array}$ \\
\hline \multicolumn{4}{|c|}{ Elodea canadensis } \\
\hline & R. subcapitata & F. pelliculosa & S. leopoliensis \\
\hline Jun & $\begin{array}{l}t=-9.346 \\
p=0.011\end{array}$ & $\begin{array}{l}t=-28.753 \\
p=0.00100\end{array}$ & $\begin{array}{l}t=-1.660 \\
p=0.239\end{array}$ \\
\hline Jul & $\begin{array}{l}t=-4.416 \\
p=0.048\end{array}$ & $\begin{array}{l}t=-3.031 \\
p=0.094\end{array}$ & $\begin{array}{l}t=-12.679 \\
p=0.00600\end{array}$ \\
\hline Aug & $\begin{array}{l}t=3.355 \\
p=0.079\end{array}$ & $\begin{array}{c}t=-0.846 \\
p=0.487\end{array}$ & $\begin{array}{l}t=0.456 \\
p=0.693\end{array}$ \\
\hline Sep & $\begin{array}{l}t=-18.571 \\
p=0.003\end{array}$ & $\begin{array}{l}t=-5.343 \\
p=0.033^{\circ}\end{array}$ & $\begin{array}{l}t=-16.065 \\
p=0.00400\end{array}$ \\
\hline
\end{tabular}

\section{Table A-III}

Pairwise ( $Z$ test after $z$ transformation of $\sqrt{ } r^{2}$ ) and multiple comparisons (Paul, 1988) of coefficients of determinations $r^{2}$, and pairwise comparisons of slopes (t-test after Zar, 2009) for the linear regressions in Figure 4. Significantly different values of $r^{2}$ according to Zar's (2009) Tukey-type test with significance threshold at $p \leqslant 0.05$, following significant Paul's (1988) $\chi^{2}$-based tests, are identified by different letters ("a" = lowest). Negative values for pairwise comparisons indicate that $r^{2}$ or slope for the lefthand regression is lower than for the righthand regression. All tests are two-tailed; df for pairwise comparisons of $r^{2}=+\infty$. Statistically significant differences are highlighted with $\bigcirc(p \leqslant 0.05), \bigcirc \bigcirc(p \leqslant 0.01)$, and $\bigcirc \bigcirc \bigcirc$ $(p \leqslant 0.0001)$.

\begin{tabular}{|c|c|c|c|c|}
\hline \multicolumn{5}{|c|}{ Nutrient-specific comparisons } \\
\hline & \multicolumn{2}{|c|}{ Phosphorus } & \multicolumn{2}{|c|}{ Nitrogen } \\
\hline$r^{2}$ & $\begin{array}{c}\chi_{\mathrm{P}}^{2}=3.467 \\
d f=2 \\
p=0.177\end{array}$ & $\begin{array}{c}\text { multiple comparison: } \\
\text { not performed }\end{array}$ & $\begin{array}{c}\chi_{\mathrm{P}}^{2}=17.131 \\
d f=2\end{array}$ & \begin{tabular}{ll}
\multicolumn{2}{c}{ multiple comparison: } \\
$r_{\text {C.dem }}^{2}$ & c \\
$r_{\text {E.can }}^{2}$ & b \\
$r_{\text {ctrl }}^{2}$ & a
\end{tabular} \\
\hline \multirow{3}{*}{ slope } & C.dem vs. ctrl: & $\begin{array}{c}t=0.231 \\
d f=20 \\
p=0.820\end{array}$ & C.dem vs. ctrl: & $\begin{array}{c}t>1000 \\
d f=20 \\
p<0.0001000\end{array}$ \\
\hline & E.can vs. ctrl: & $\begin{array}{c}t=-0.428 \\
d f=20 \\
p=0.673\end{array}$ & E.can vs. ctrl: & $\begin{array}{c}t=2.730 \\
d f=20 \\
p=0.013^{\circ}\end{array}$ \\
\hline & C.dem vs. E.can: & $\begin{array}{c}t>1000 \\
d f=20 \\
p<0.0001000\end{array}$ & C.dem vs. E.can: & $\begin{array}{c}t>1000 \\
d f=20 \\
p<0.0001000\end{array}$ \\
\hline
\end{tabular}

\begin{tabular}{|c|c|c|c|}
\hline \multicolumn{4}{|c|}{ Comparisons by experimental condition (N vs. P) } \\
\hline & C.dem & E.can & ctrl \\
\hline \multirow{2}{*}{$r^{2}$} & $Z=2.882$ & $Z=0.929$ & $Z=3.353$ \\
& $p=0.004 \bigcirc 0$ & $p=0.353$ & $p=0.0008$ \\
\hline
\end{tabular}




\section{Table A-IV}

Average net nutrient $(N, P)$ daily uptake rate estimates (as $\mu g \cdot g^{-1} \cdot f w \cdot d^{-1}, \pm$ standard error; $n=3$ for each) for macrophyte sprigs in $R$. subcapitata flasks, by month. Positive numbers indicate net nutrient uptake by sprigs, and negative numbers indicate net nutrient loss from sprigs; $\bullet=$ rates associated with significant algal growth inhibition, as per $d_{4}$ HSD tests in Appendix Table A-I.

\begin{tabular}{|c|c|c|c|c|}
\cline { 2 - 5 } \multicolumn{1}{c|}{} & \multicolumn{2}{c|}{ C. demersum } & \multicolumn{2}{c|}{ E. canadensis } \\
\cline { 2 - 5 } \multicolumn{1}{c|}{ Jun } & $\mathbf{P}$ & $\mathrm{N}$ & $\mathrm{P}$ & $\mathrm{N}$ \\
& $\pm .5^{\bullet}$ & $24.2^{\bullet}$ & -20.4 & 5.7 \\
& \pm 0.7 & \pm 1.3 & \pm 10.2 & \pm 4.3 \\
\hline \multirow{2}{*}{ Jul } & -1.1 & 104.6 & -6.3 & 87.1 \\
& \pm 1.3 & \pm 3.9 & \pm 1.8 & \pm 6.6 \\
\hline \multirow{2}{*}{ Aug } & $5.8^{\bullet}$ & $104.0^{\bullet}$ & $3.8^{\bullet}$ & $97.8^{\bullet}$ \\
& \pm 0.1 & \pm 2.9 & \pm 3.0 & \pm 12.6 \\
\hline \multirow{2}{*}{ Sep } & 6.5 & 3.4 & -38.4 & -269.3 \\
& \pm 0.5 & \pm 4.9 & \pm 5.1 & \pm 17.0 \\
\hline
\end{tabular}

\section{Table A-V}

Inside-vs.-outside macrophyte stand biovolume comparisons (paired-sample two-tailed t-tests) for total phytoplankton and major groups in C. demersum-dominated Spiradammen and E. canadensisdominated Østensjøvatn. Tests were performed on square-root-transformed, pooled monthly data (in $\left.\mathrm{mm}^{3} \cdot \mathrm{m}^{-3}\right) ; n=4$ and $d f=3$ for each comparison. Negative $t$ values represent average biovolumes lower at inside-stand sites. Significant $t$ values are highlighted with $\bigcirc(p \leqslant 0.05), \bigcirc(p \leqslant 0.01)$, and $\bigcirc \bigcirc \bigcirc$ $(p \leqslant 0.0001)$.

\begin{tabular}{|l|c|c|}
\cline { 2 - 3 } \multicolumn{1}{c|}{} & Spiradammen & Østensjøvatn \\
\hline \multirow{2}{*}{ total phytoplankton } & $t=0.659$ & $t=-3.321$ \\
& $p=0.557$ & $p=0.045$ \\
\hline \multirow{2}{*}{ Cyanophyceae } & $t=-0.747$ & $t=-1.701$ \\
& $p=0.509$ & $p=0.188$ \\
\hline \multirow{2}{*}{ Chlorophyceae } & $t=-1.817$ & $t=-0.428$ \\
& $p=0.167$ & $p=0.698$ \\
\hline \multirow{2}{*}{ Bacillariophyceae } & $t=0.647$ & $t=-1.910$ \\
& $p=0.564$ & $p=0.152$ \\
\hline \multirow{2}{*}{ Chrysophyceae } & $t=-0.011$ & $t=-0.622$ \\
& $p=0.992$ & $p=0.578$ \\
\hline \multirow{2}{*}{ Cryptophyceae } & $t=-0.044$ & $t=-1.555$ \\
& $p=0.968$ & $p=0.218$ \\
\hline \multirow{2}{*}{ Dinophyceae } & $t=1.895$ & $t=2.787$ \\
& $p=0.154$ & $p=0.069$ \\
\hline
\end{tabular}


Table A-VI

Inside-vs.-outside macrophyte stand percent relative abundance comparisons (paired-sample two-tailed t-tests) for selected phytoplankton taxa in C. demersum-dominated Spiradammen and E. canadensisdominated Østensjøvatn. Tests were performed on arcsine-transformed, pooled monthly data; $n=4$ and $d f=3$ for each comparison. Negative $t$ values represent relative abundances lower inside macrophyte stands. Significant differences for $p \leqslant 0.05(\bigcirc), p \leqslant 0.01(\bigcirc \bigcirc)$, and $p \leqslant 0.0001(\bigcirc \bigcirc)$. Phytoplankton taxa are listed alphabetically; nomenclature after Guiry and Guiry (2012). Taxon groups: BAC = bacillariophytes (diatoms), CYA = cyanobacteria, $\mathrm{CHL}=$ chlorophytes, $\mathrm{CHR}=$ chrysophytes, $\mathrm{CRY}=$ cryptophytes, DIN = dinophytes; "-" = taxon absent; "nc" = not calculable (taxon observed in <3 monthly samplings).

\begin{tabular}{|c|c|c|c|}
\hline Taxon & Group & Spiradammen & Ostensjøvath \\
\hline $\begin{array}{l}\text { Aulacoseira (=Melosira) italica var.tenuissima } \\
\text { (Grunow) Simonsen }\end{array}$ & BAC & - & $\begin{array}{l}t=-0.988 \\
p=0.396\end{array}$ \\
\hline $\begin{array}{l}\text { Botryococcus braunii } \\
\text { Kützing }\end{array}$ & $\overline{\mathrm{CHL}}$ & $\begin{array}{l}t=-1.785 \\
p=0.172\end{array}$ & $\mathrm{nc}$ \\
\hline $\begin{array}{l}\text { Ceratium cornutum } \\
\text { (Ehrenberg) Claparède \& J.Lachmann }\end{array}$ & $\overline{D I N}$ & $\begin{array}{l}t=1.220 \\
p=0.310\end{array}$ & - \\
\hline $\begin{array}{l}\text { Cryptomonas curvata } \\
\text { Ehrenberg }\end{array}$ & $\overline{C R Y}$ & $\mathrm{nc}$ & $\begin{array}{l}t=1.731 \\
p=0.182\end{array}$ \\
\hline $\begin{array}{l}\text { Cryptomonas erosa }^{1} \\
\text { Ehrenberg }\end{array}$ & CRY & $\begin{array}{l}t=-1.352 \\
p=0.269\end{array}$ & $\begin{array}{l}t=-1.054 \\
p=0.369\end{array}$ \\
\hline $\begin{array}{l}\text { Dolichospermum (=Anabaena) lemmermannii } \\
\text { (P. Richter) P. Wacklin, L. Hoffmann \& J. Komárek }\end{array}$ & CYA & - & $\begin{array}{l}t=-0.648 \\
p=0.563\end{array}$ \\
\hline $\begin{array}{l}\text { Dolichospermum (=Anabaena) planctonicum } \\
\text { (Brunnth.) Wacklin, L.Hoffm. \& Komárek }\end{array}$ & $\overline{C Y A}$ & - & $\begin{array}{l}t=-1.005 \\
p=0.389\end{array}$ \\
\hline $\begin{array}{l}\text { Dolichospermum (=Anabaena) spiroides } \\
\text { (Kleb.) Wacklin, L.Hoffm. \& Komárek }\end{array}$ & CYA & - & $\begin{array}{l}t=1.977 \\
p=0.142\end{array}$ \\
\hline Fragilaria spp. & $\overline{B A C}$ & - & $\begin{array}{l}t=0.649 \\
p=0.563\end{array}$ \\
\hline Gymnodinium spp. & $\overline{D I N}$ & $\begin{array}{l}t=0.823 \\
p=0.471\end{array}$ & $\begin{array}{l}t=1.601 \\
p=0.208\end{array}$ \\
\hline $\begin{array}{l}\text { Katablepharis ovalis } \\
\text { Skuja }\end{array}$ & $\overline{C R Y}$ & $\begin{array}{l}t=2.703 \\
p=0.074\end{array}$ & $\begin{array}{l}t=1.040 \\
p=0.375\end{array}$ \\
\hline Mallomonas spp. & $\mathrm{CHR}$ & $\mathrm{nc}$ & $\begin{array}{l}t=-1.691 \\
p=0.189\end{array}$ \\
\hline Microcystis spp. & $\overline{C Y A}$ & - & $\begin{aligned} t & =0.923 \\
p & =0.424\end{aligned}$ \\
\hline $\begin{array}{l}\text { Monoraphidium (=Ankistrodesmus) contortum } \\
\text { (Thuret) Komàrková-Legnerová }\end{array}$ & $\overline{\mathrm{CHL}}$ & - & $\begin{array}{l}t=-0.552 \\
p=0.619\end{array}$ \\
\hline $\begin{array}{l}\text { Monoraphidium (=Raphidium) minutum } \\
\text { (Nägeli) Komárková-Legnerová }\end{array}$ & $\mathrm{CHL}$ & $\begin{array}{l}t=-0.545 \\
p=0.624\end{array}$ & $\mathrm{nc}$ \\
\hline Peridinium spp. & $\overline{D I N}$ & $\begin{array}{l}t=0.875 \\
p=0.446\end{array}$ & $\begin{array}{l}t=1.681 \\
p=0.191\end{array}$ \\
\hline $\begin{array}{l}\text { Raphidocelis (=Pseudokirchneriella) subcapitata } \\
\text { (Korshikov) G. Nygaard, J. Komárek, } \\
\text { J. Kristiansen \& O.M. Skulberg }\end{array}$ & $\overline{\mathrm{CHL}}$ & $\begin{array}{l}t=-1.689 \\
p=0.190\end{array}$ & nc \\
\hline $\begin{array}{l}\text { Rhodomonas lacustris }{ }^{2} \\
\text { Pascher \& Ruttner }\end{array}$ & $\overline{C R Y}$ & $\begin{aligned} t & =0.035 \\
p & =0.974\end{aligned}$ & $\begin{array}{l}t=-1.197 \\
p=0.317\end{array}$ \\
\hline $\begin{array}{l}\text { Scenedesmus arcuatus } \\
\text { Lemmermann }\end{array}$ & $\mathrm{CHL}$ & $\begin{aligned} t & =2.425 \\
p & =0.094\end{aligned}$ & - \\
\hline Scenedesmus spp. & $\overline{\mathrm{CHL}}$ & - & $\begin{array}{l}t=1.140 \\
p=0.337\end{array}$ \\
\hline $\begin{array}{l}\text { Stephanodiscus hantzschii }{ }^{3} \\
\text { Grunow }\end{array}$ & BAC & - & $\begin{aligned} t & =2.040 \\
p & =0.134\end{aligned}$ \\
\hline $\begin{array}{l}\text { Uroglenopsis (=Uroglena) americana } \\
\text { (Calkins) Lemmermann }\end{array}$ & $\mathrm{CHR}$ & $\begin{array}{l}t=1.309 \\
p=0.282\end{array}$ & - \\
\hline $\begin{array}{l}\text { Woronichinia (=Gomphosphaeria) naegeliana } \\
\text { (Unger) Elenkin }\end{array}$ & $\overline{C Y A}$ & $\begin{array}{l}t=-0.899 \\
p=0.435\end{array}$ & - \\
\hline
\end{tabular}

\footnotetext{
1 includes var. reflexa.

2 includes var. nannoplanctonica.

3 includes var. pusillus.
} 


\section{ESTIMATION OF DAILY NUTRIENT UPTAKE BY EXPERIMENTAL SPRIGS: OUTLINE OF METHODS}

Sprig net nutrient (N, P) uptake rates were estimated using Hilt and Lombardo's (2010) concentration-based mass balance approach. The average quantity of nutrients removed by $R$. subcapitata (from control flasks) was subtracted from each flask-specific total (sprig+algal) quantity of nutrients removed in each sprig-present flask. The latter was given by the difference between final (measured) and initial (nominal) concentration (e.g., Hilt and Lombardo, 2010). The quantity of removed nutrients was then divided by average sprig biomass [as (final+initial)/2] and by experimental duration (4 d) to produce daily uptake rate estimates (as $\mu \mathrm{g}$ of $\mathrm{N}$ or $\mathrm{P}$ removed daily per $\mathrm{g}$ of sprig fresh weight) for each plant species in each month. Although such a method does not allow to fully separate nutrient uptake by coexisting macrophytes, periphyton, and phytoplankton, the short experimental time (Lombardo and Cooke, 2003) and the higher macrophyte biomass typically lead to significantly higher total macrophyte than total microalgal uptake rates (Pelton et al., 1998; Hilt and Lombardo, 2010), allowing for a coarse yet sufficiently reliable flask-based estimate of sprig nutrient uptake rates. 